\title{
PLATE I
}

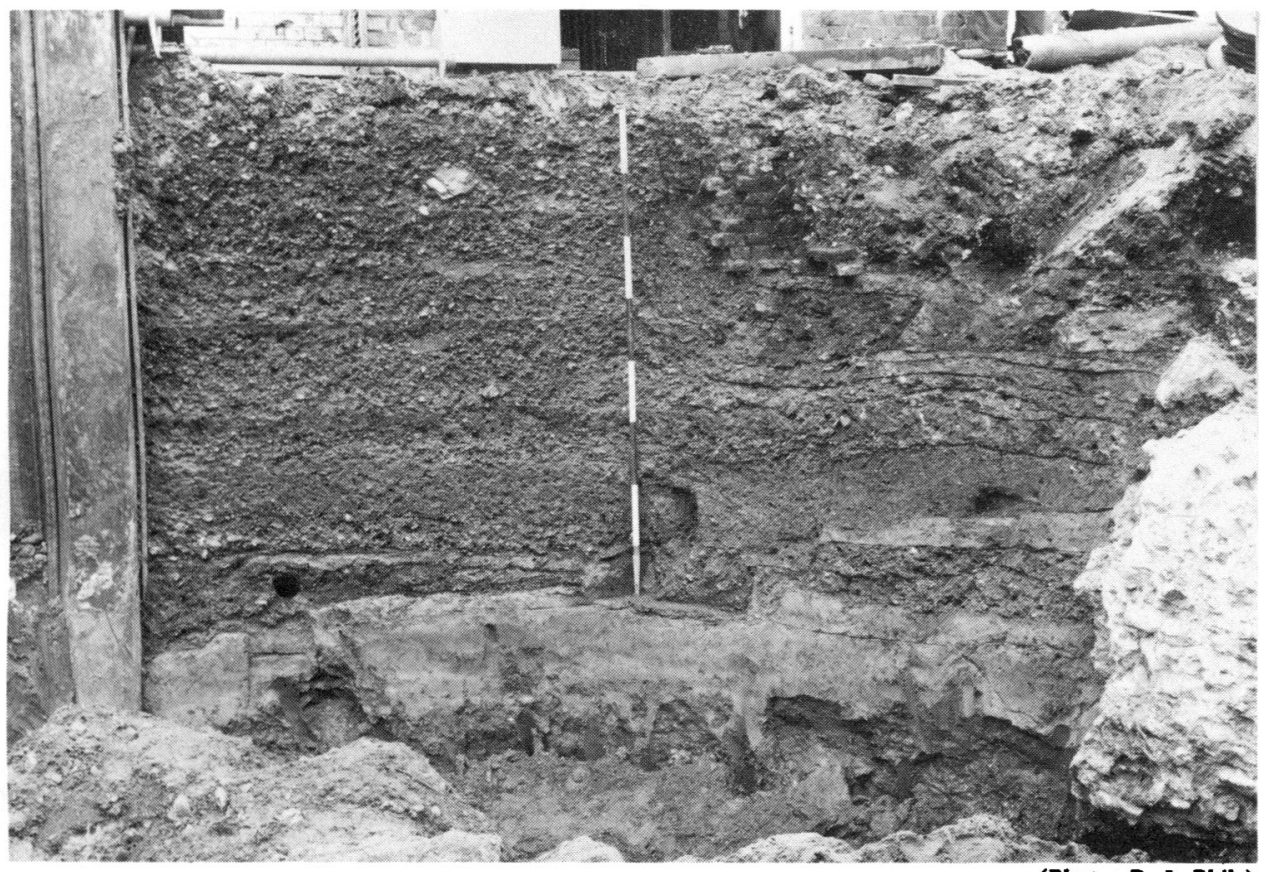

(Photo: B. J. Philp)

A. London, Forum Site. Successive layers of metalling of main east-west road (Periods I to V) (p. 25 f.). Scale in feet.

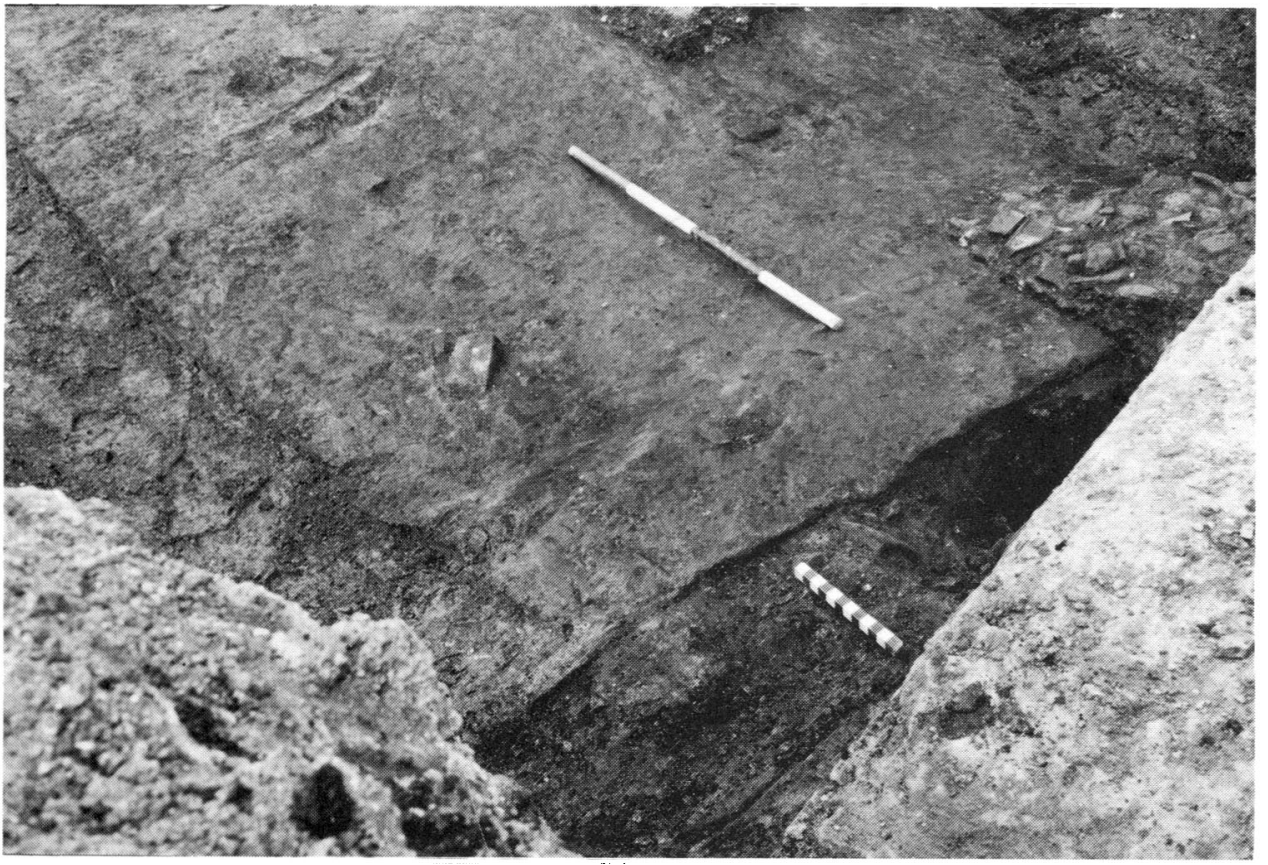

(Photo: B. J. Philp)

B. London, Forum Site. Burnt clay floor, fire-debris and foundation-trench (foreground) of

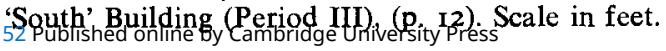




\section{PLATE II}

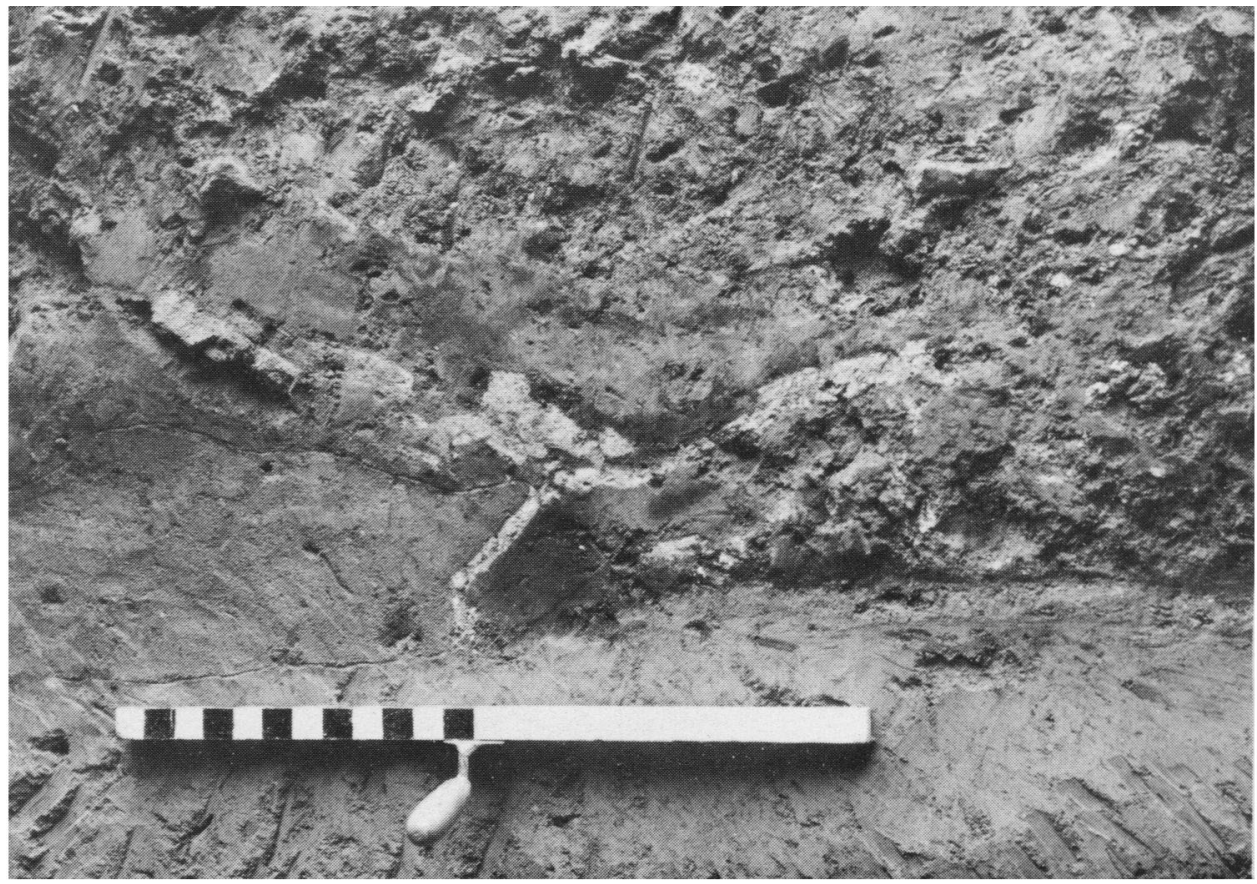

(Photo: B. J. Philp)

A. London, Forum Site. Section of collapsed plastered walls in fire-debris of 'North' building (Period III) (p. I5). Scale: 2 feet.

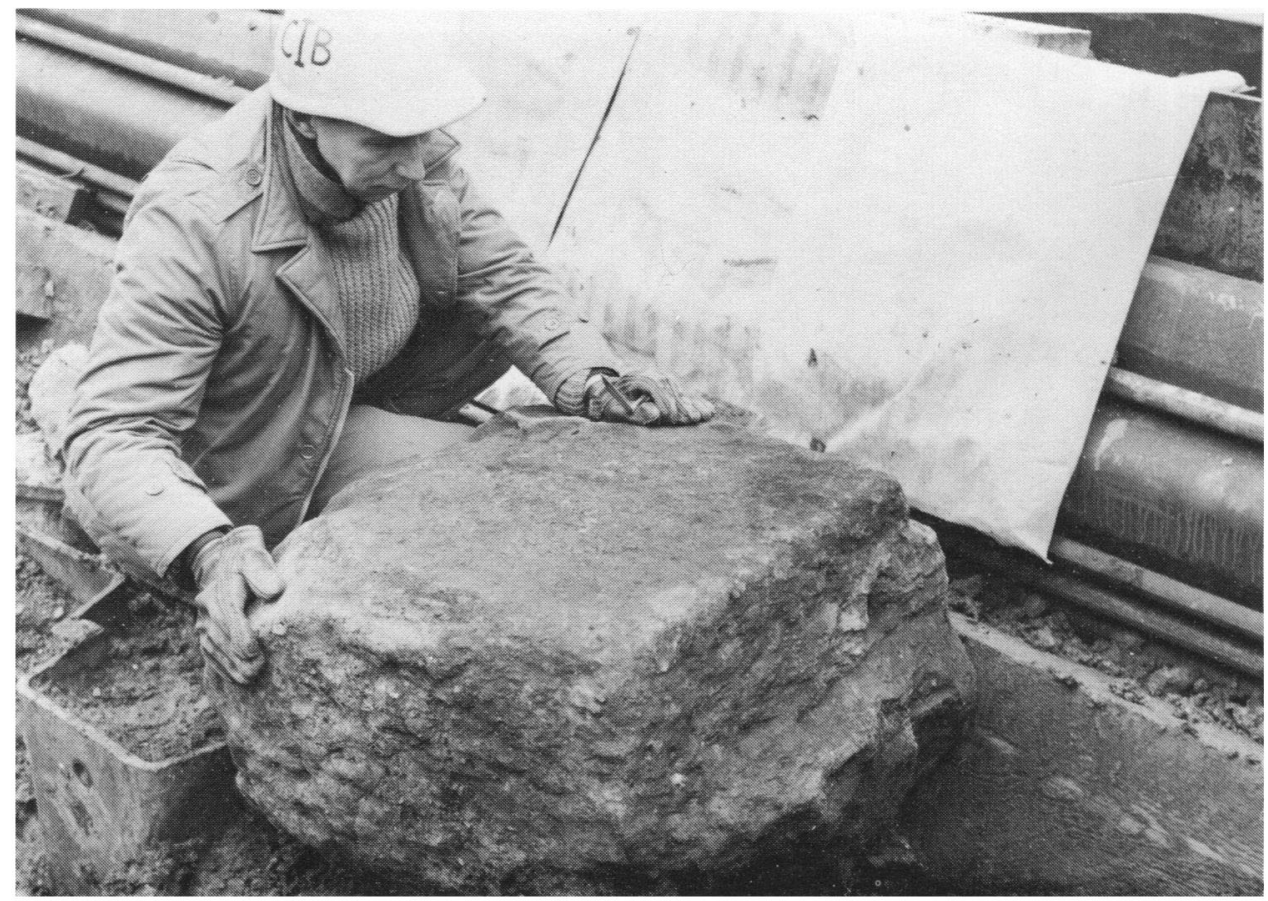

(Photo: B. J. Philp)

B. London, Forum Site. Ragstone block from 'South' Building (Period III) after extraction by

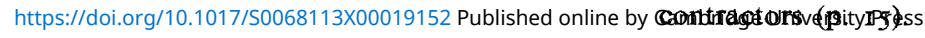




\section{PLATE III}

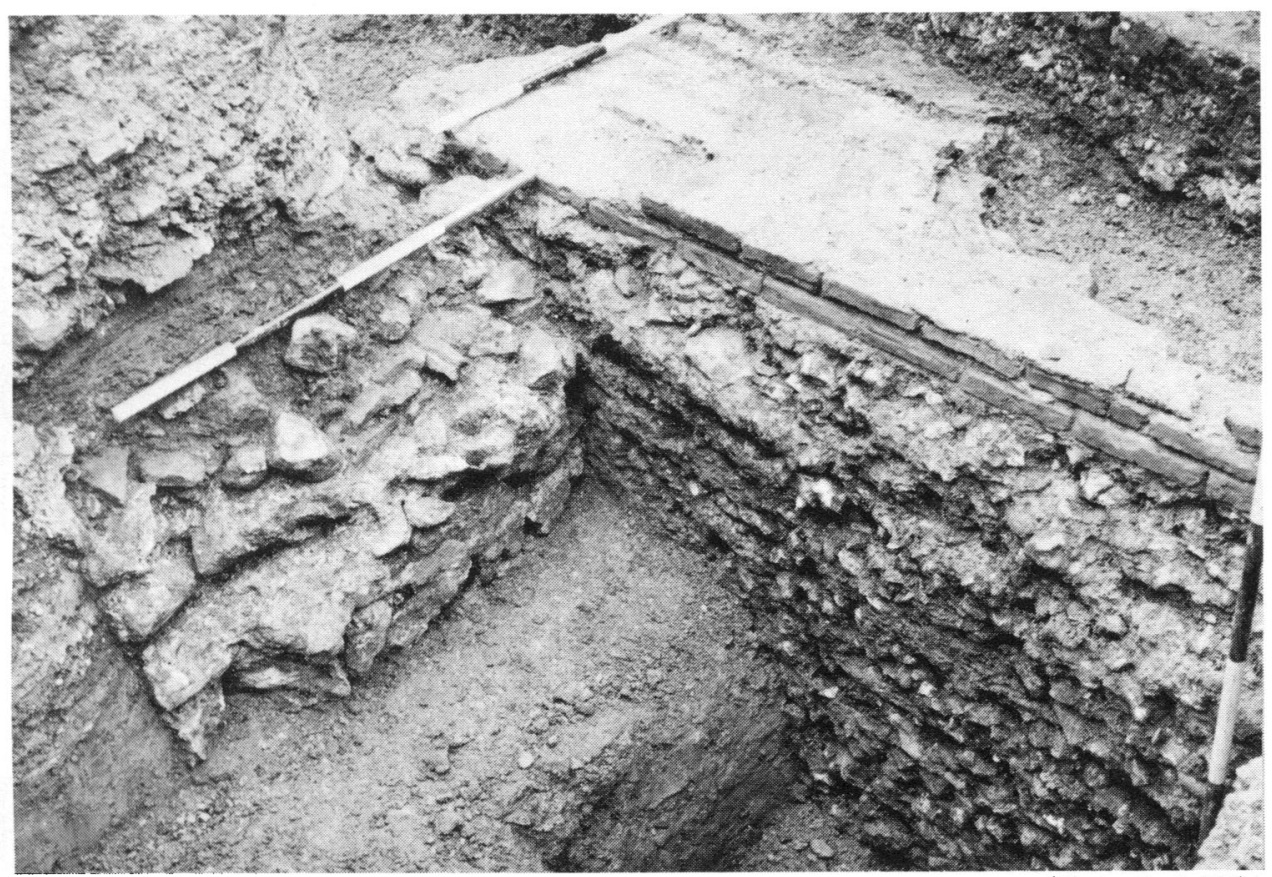

(Photo: B. J. Philp)

A. London, Forum Site. External south wall of proto-forum (Period IV) with (on left) inserted forum pier-base (Period V), p. I7). Scale in feet.

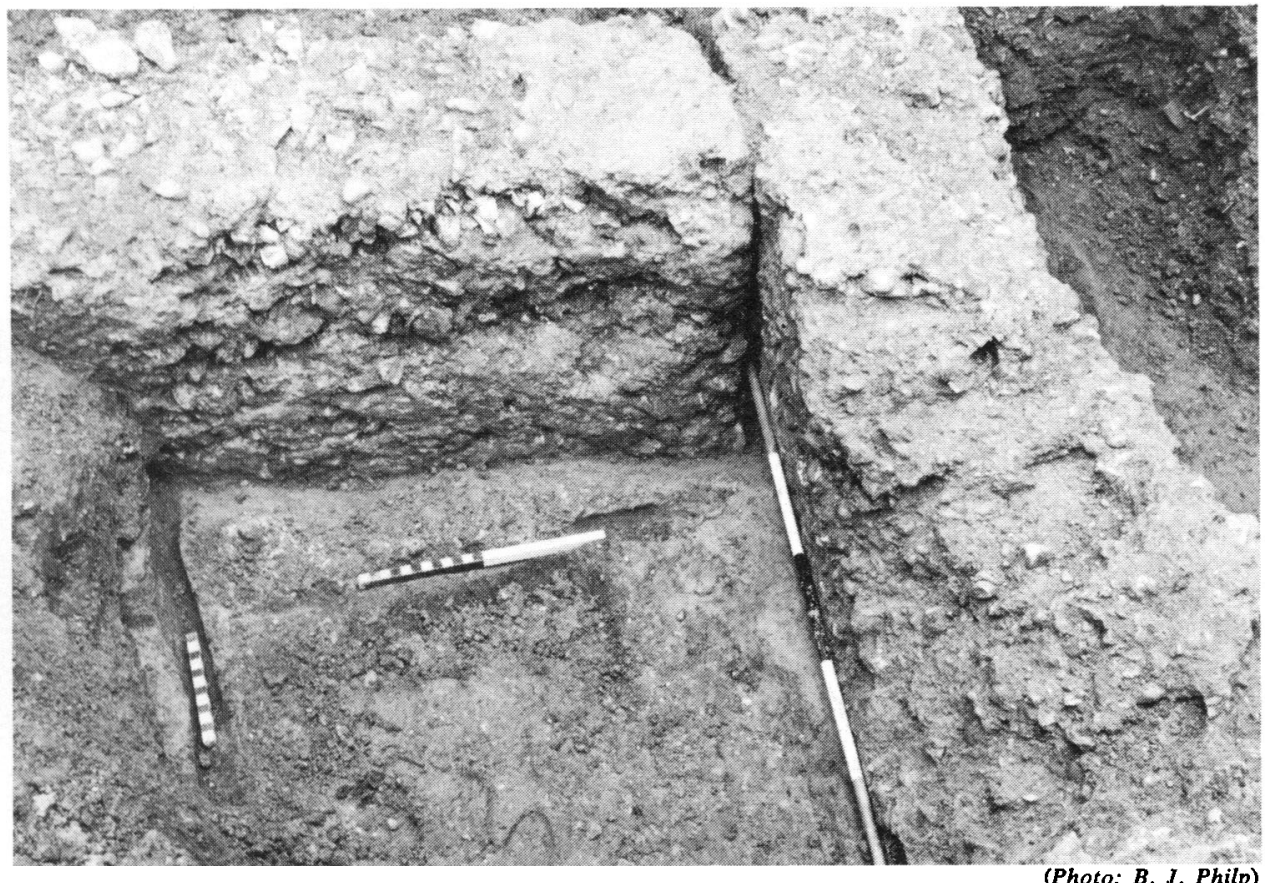

B. London, Forum Site. Internal east wall (right) of proto-forum (Period IV) with butted cross-

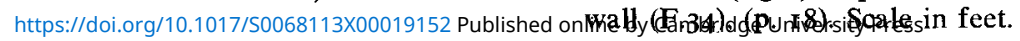


PLATE IV
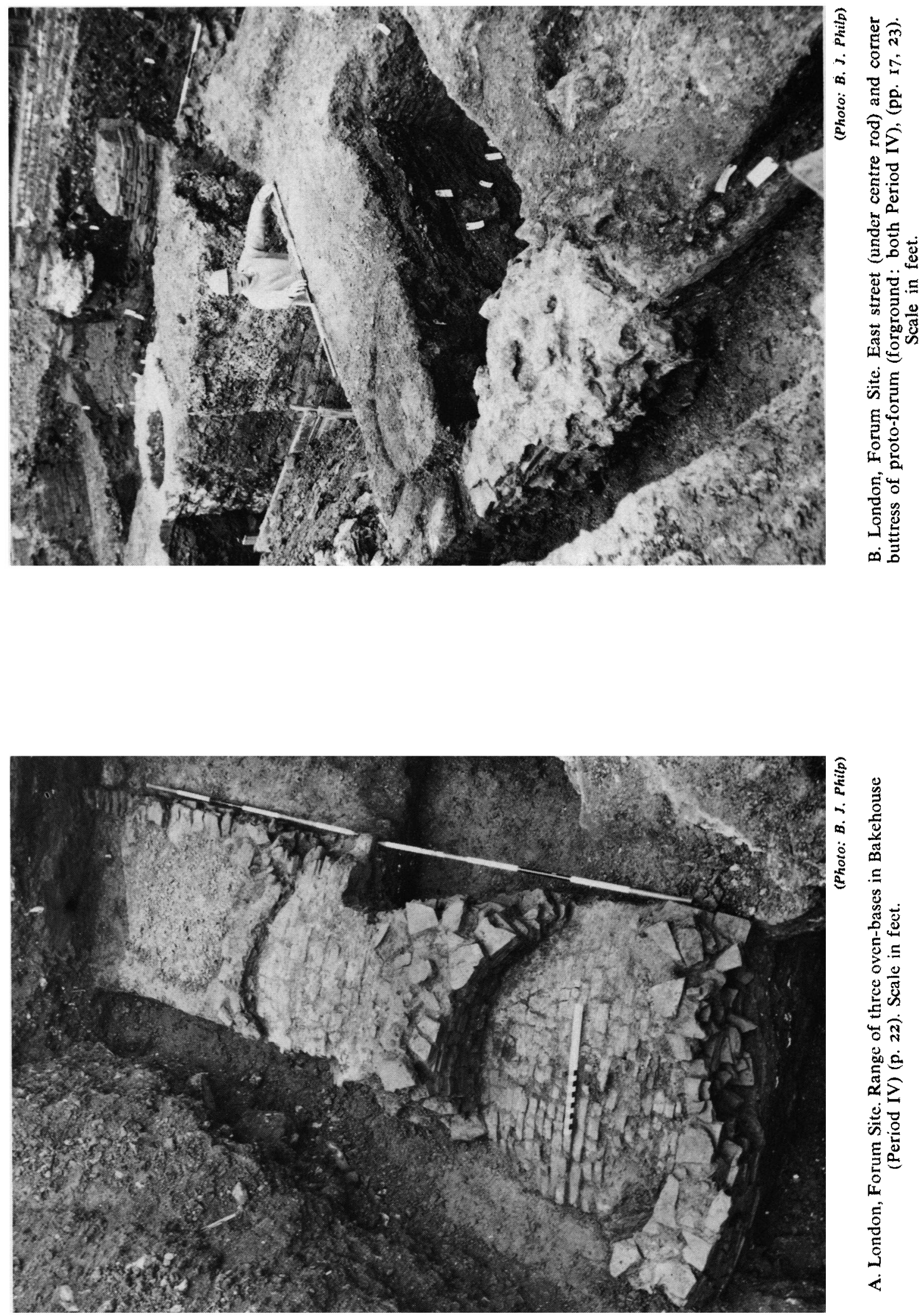


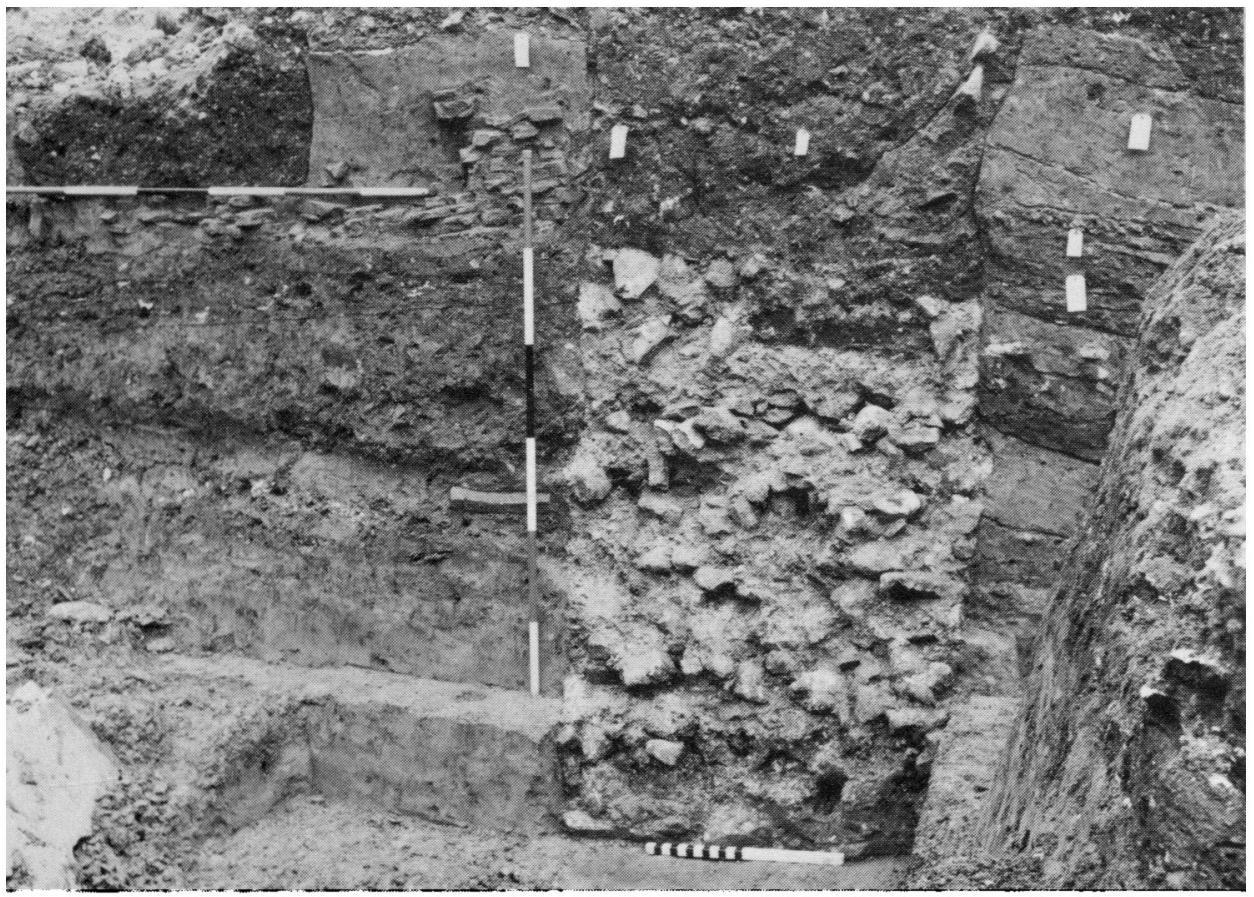

(Photo: B. J. Philp)

A. London, Forum site. South-centre foundation of South Range of Forum (Period V), (p. 24). Scale in feet.

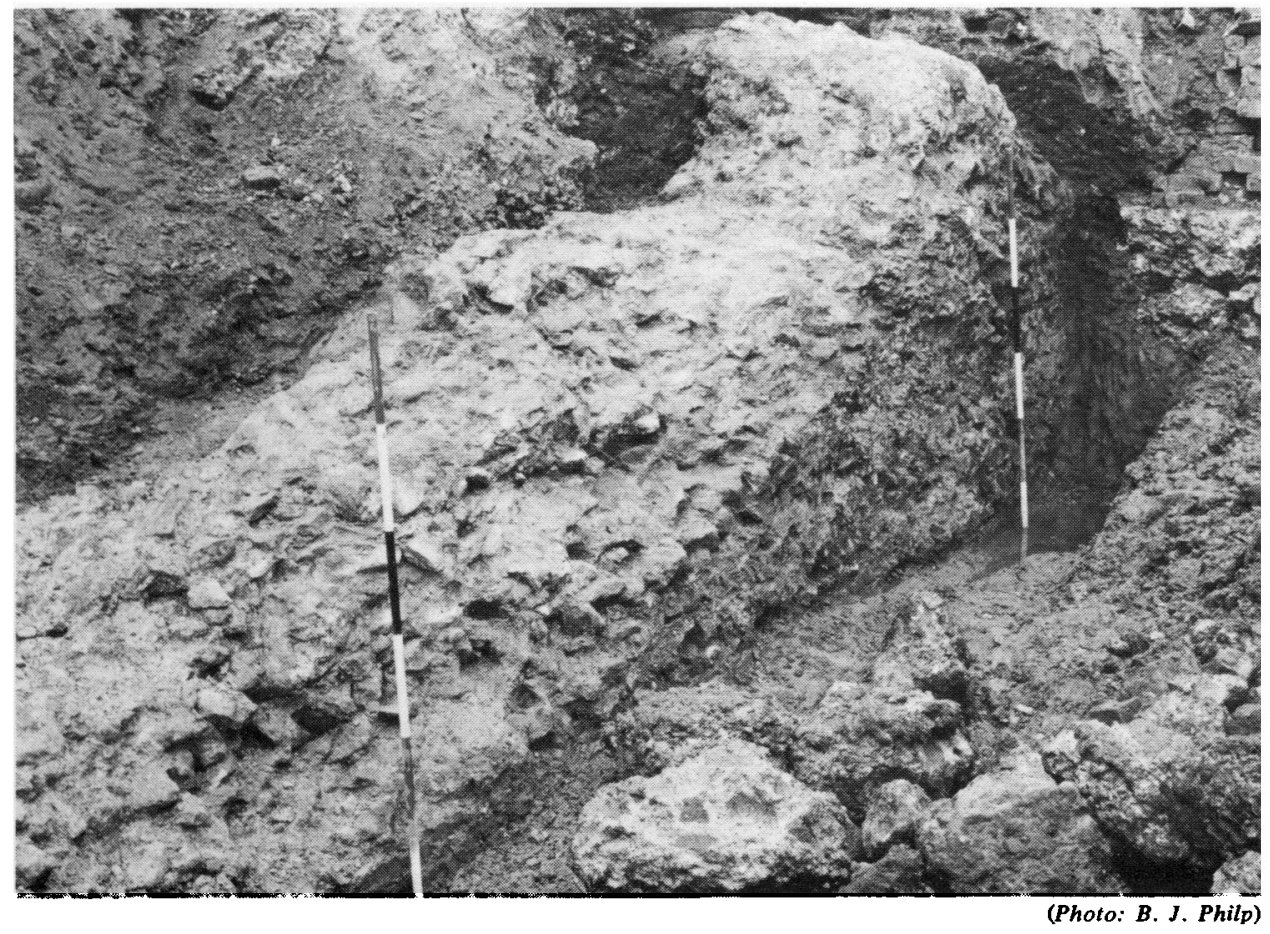

B. London, Forum Site. South foundation of South Range of Forum (Period V) https://doi.org/10.1017/S0068113X00019152 Published dolinigy demboildirouni(pr.siz/4)reSicale in feet. 
PLATE VI

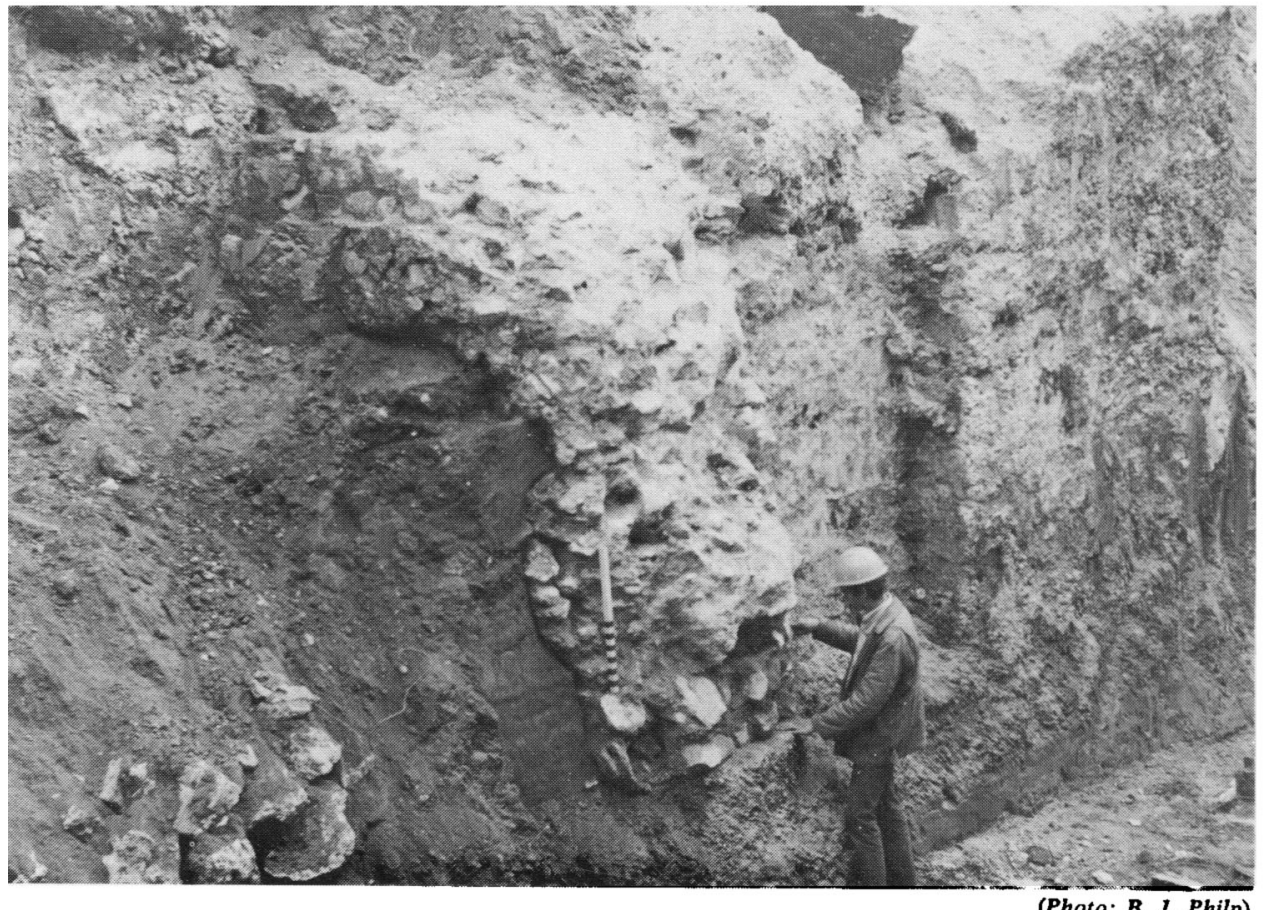

(Photo: B. J. Philp)

London, Forum Site. West-centre foundation of East Range of Forum (Period V), (p. 27).

Scale: feet.

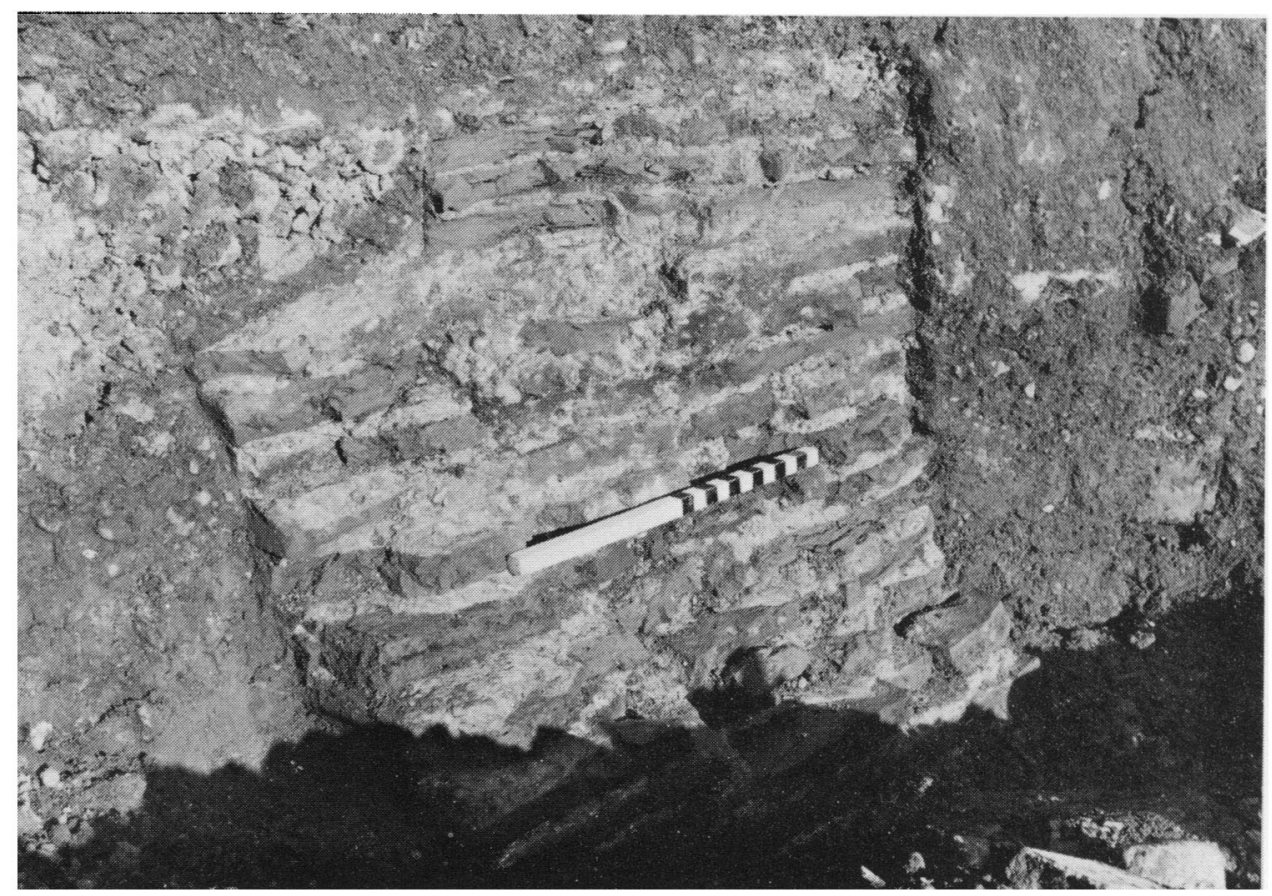

(Photo: B. J. Philp)

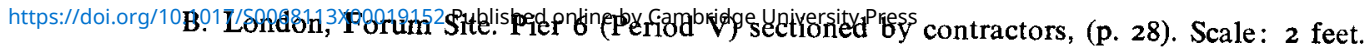



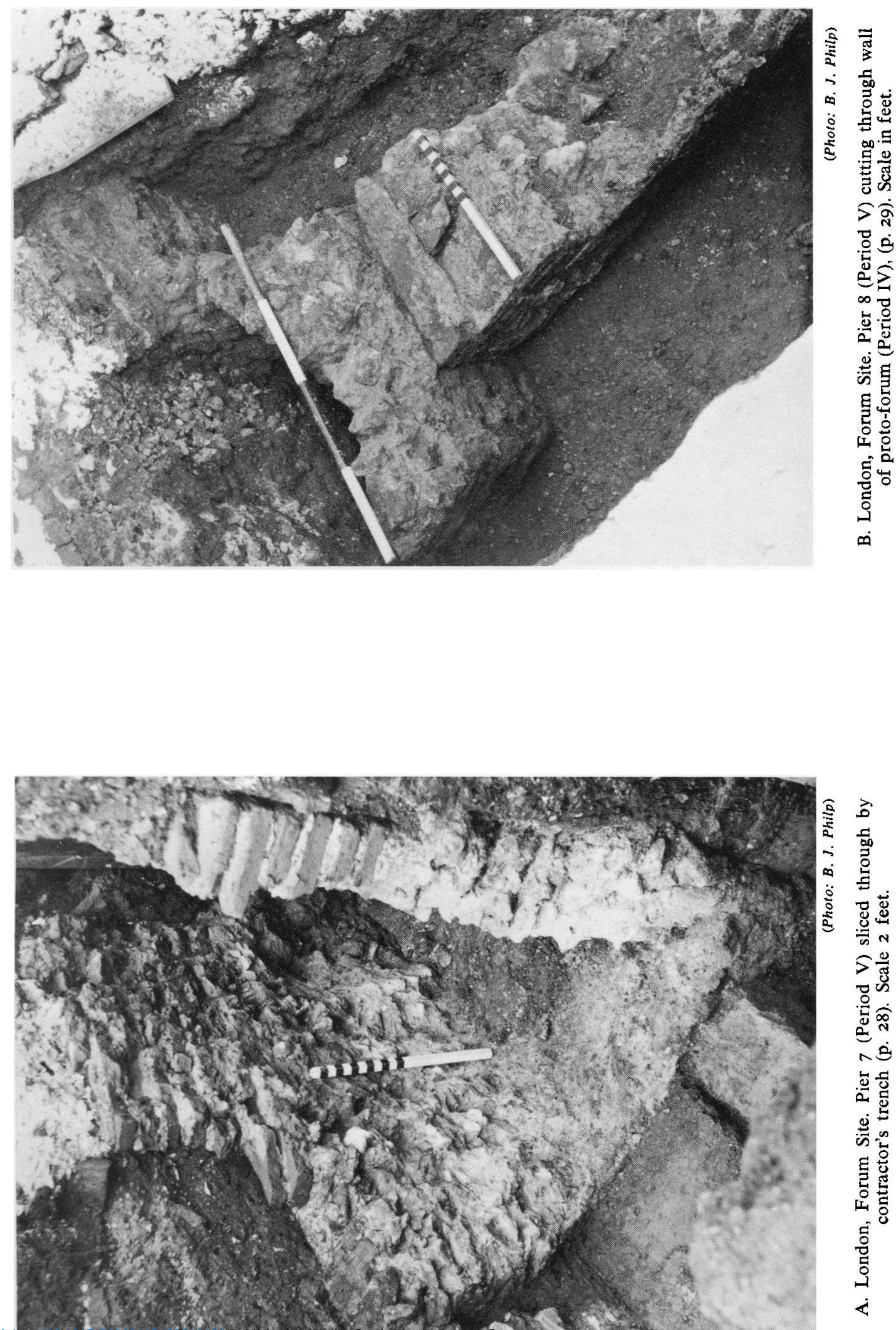

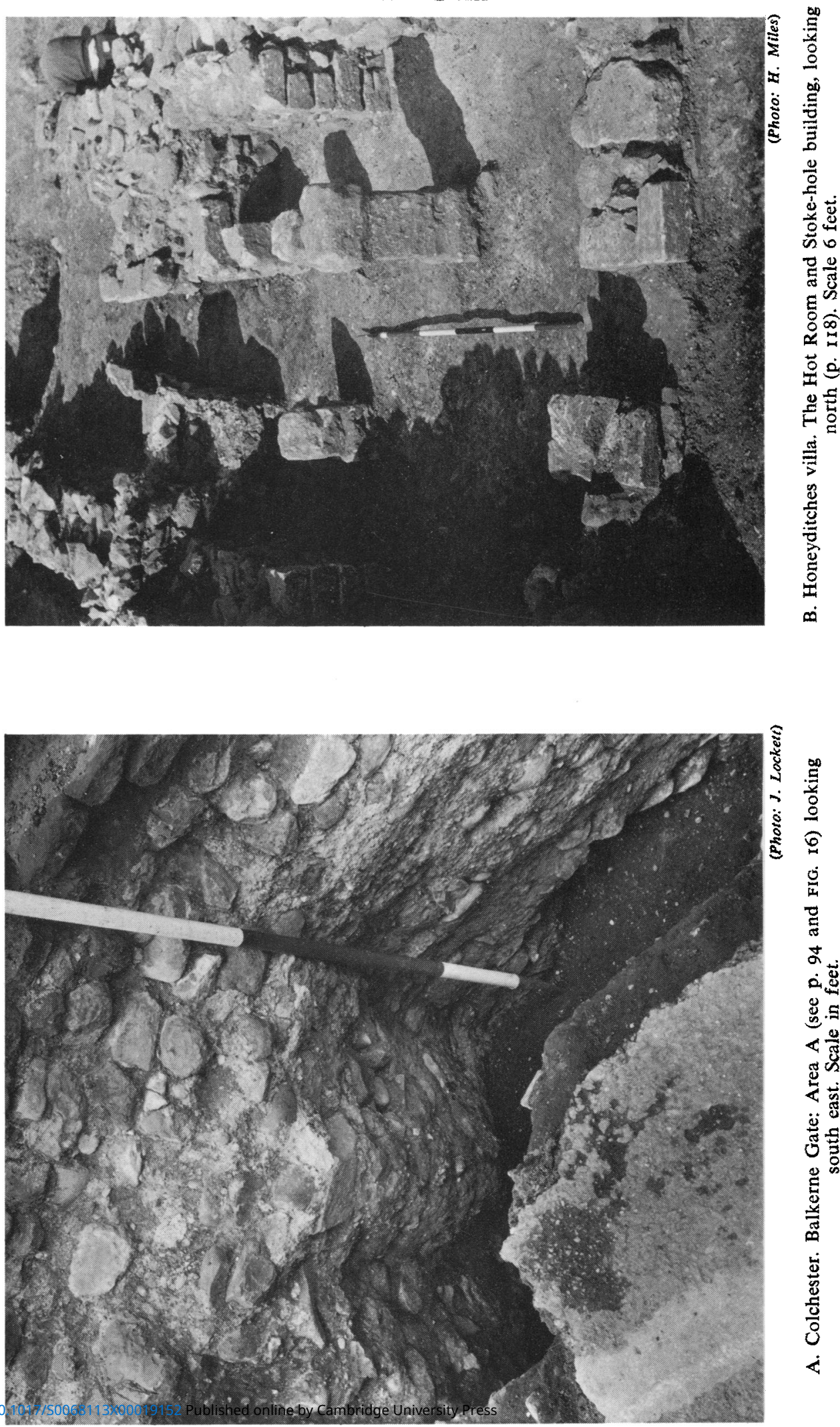


\section{PLATE IX}

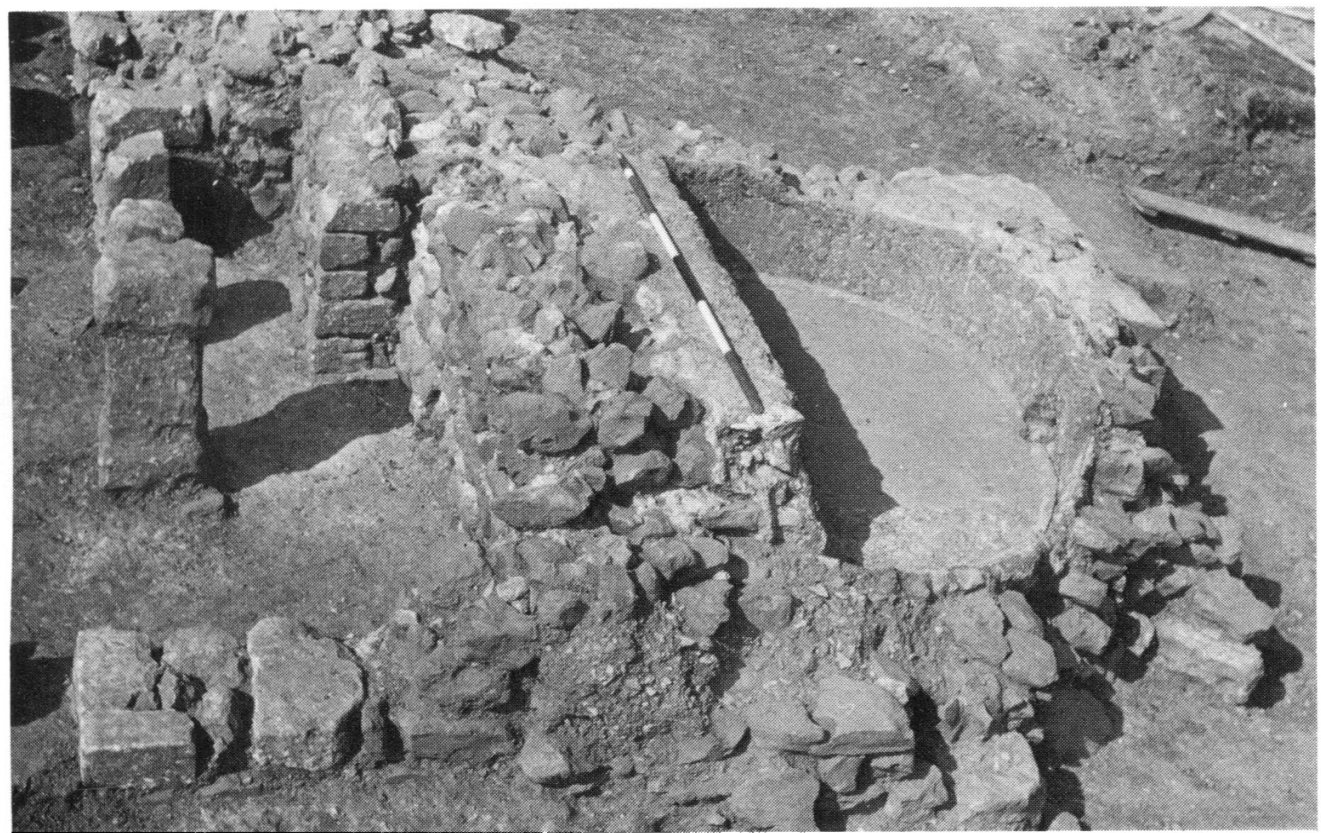

(Photo: H. Miles)

A. Honeyditches villa. The plaster-lined bath and part of the Hot Room, looking north (p. II8). Scale 6 feet.

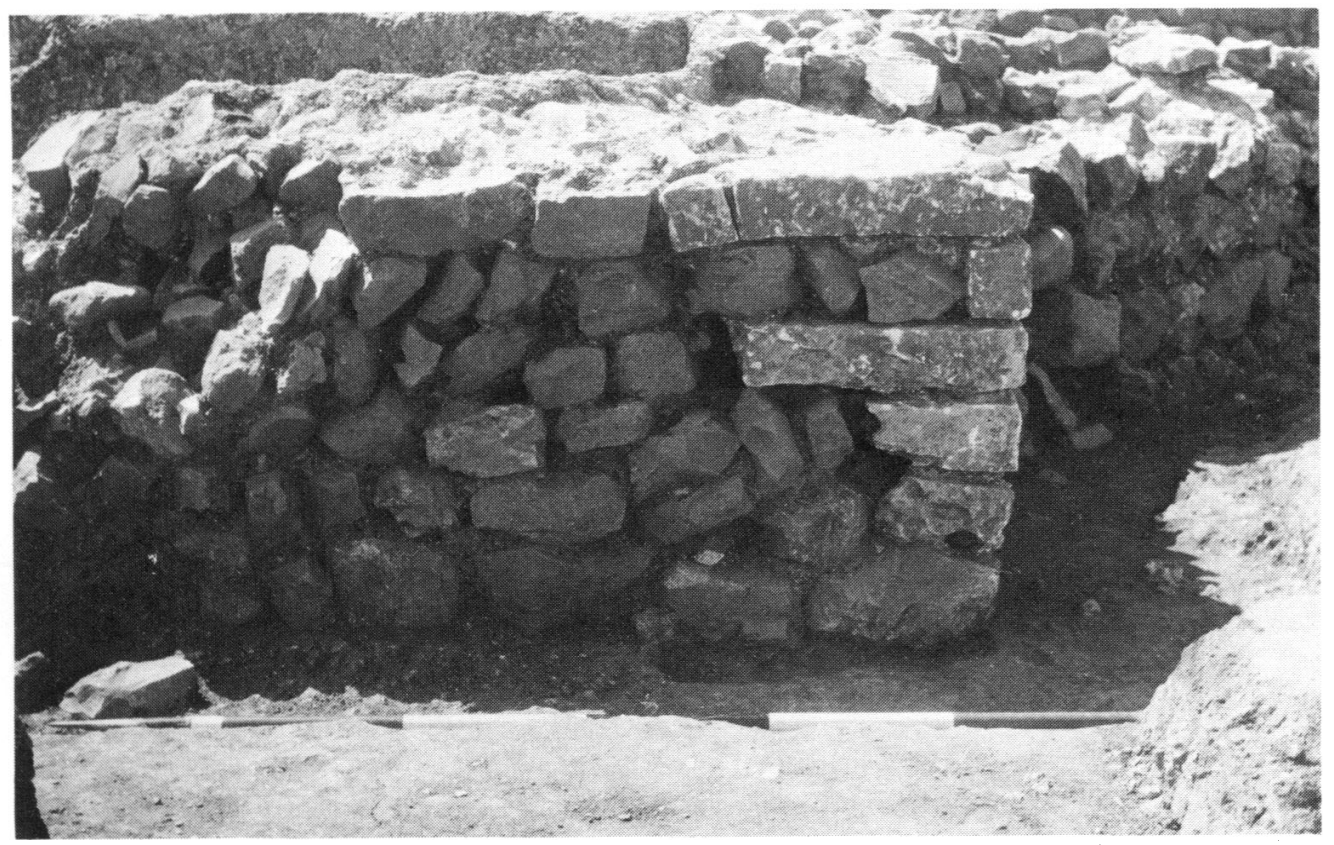

(Photo: H. Miles)

B. Honeyditches villa. Beer-stone ashlar quoins and chert walling on the outside of the bath

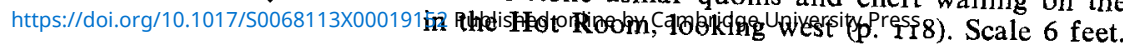




\section{PLATE $\mathrm{X}$}
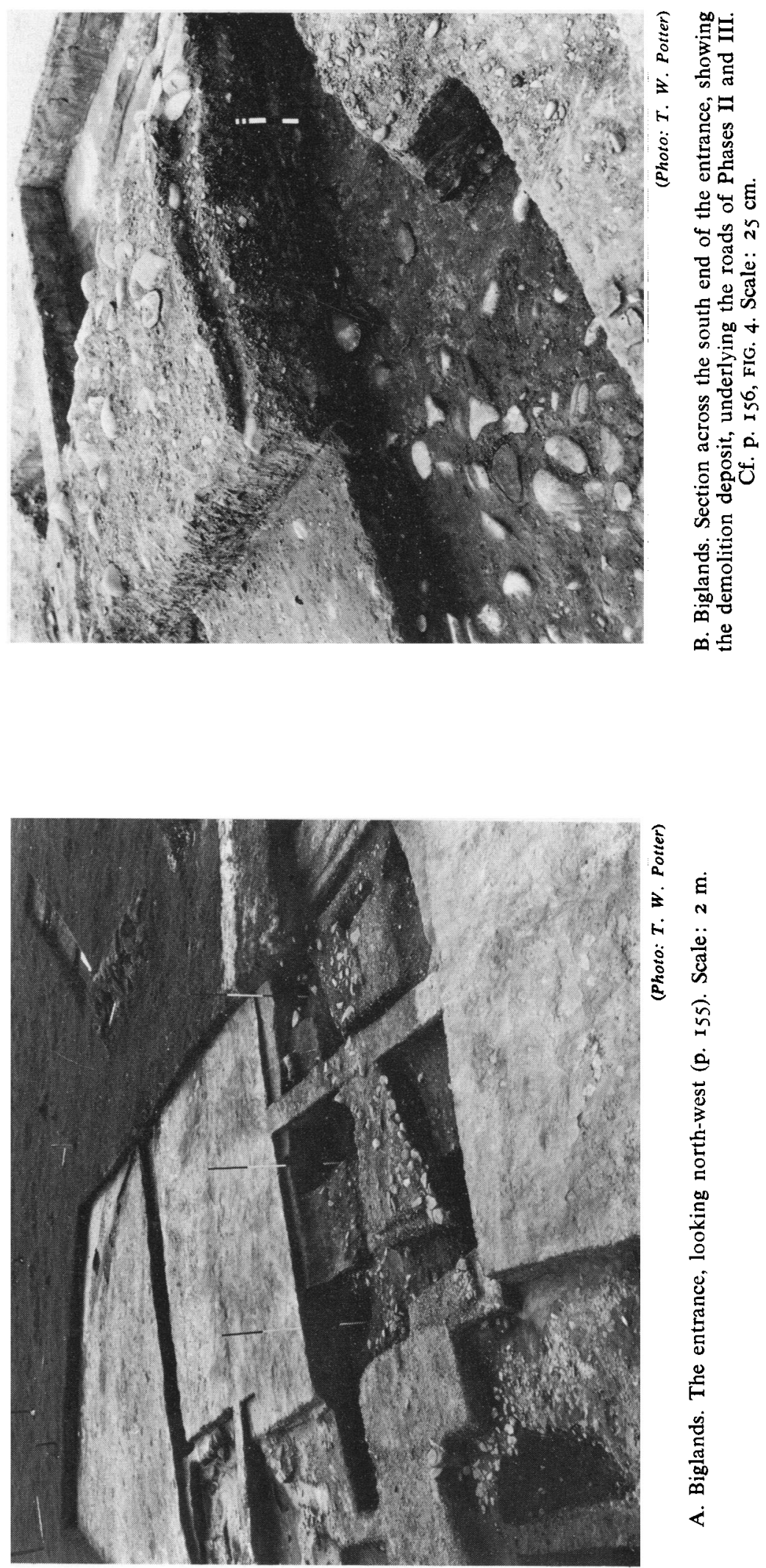

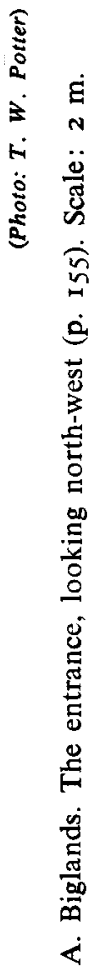




\section{PLATE XI}

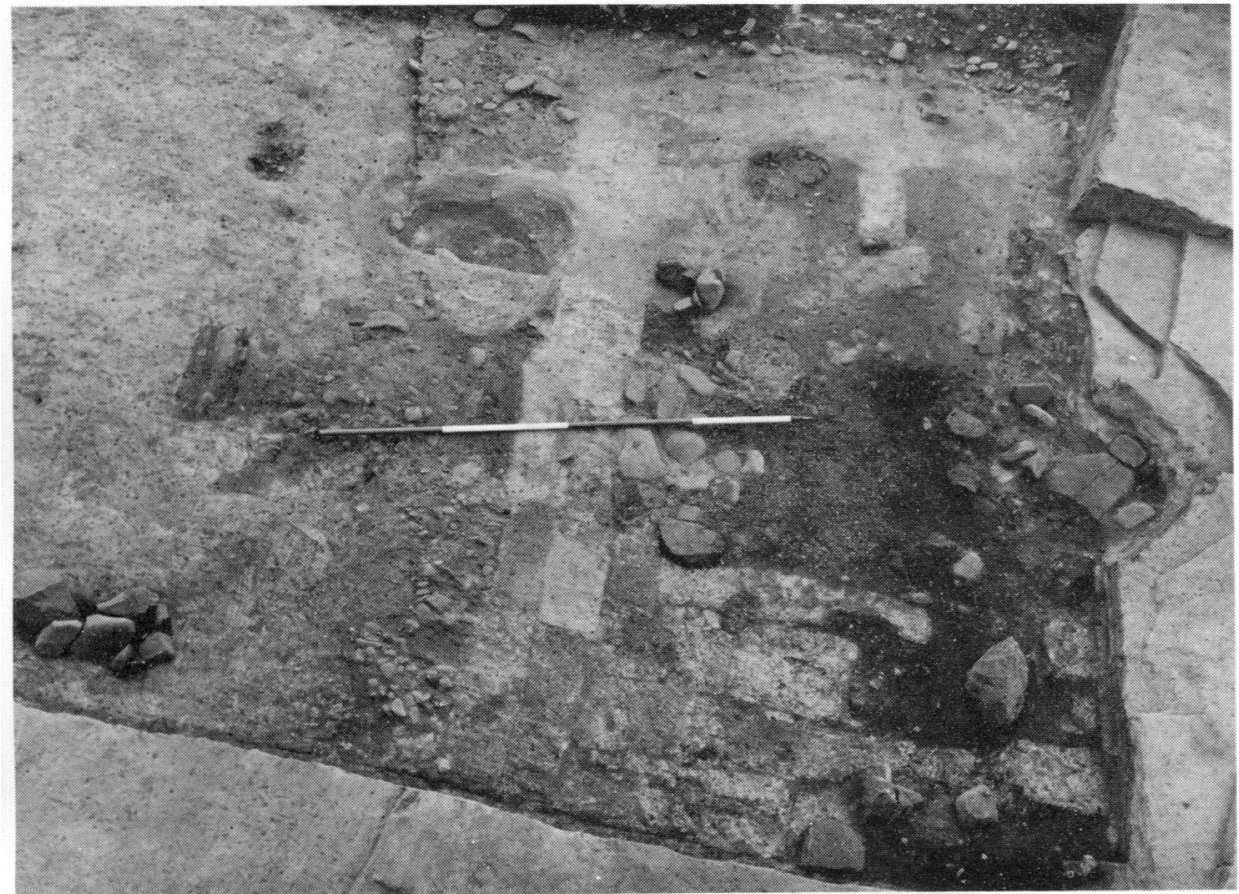

(Photo: T. W. Potter)

A. Biglands. Turf wall enclosing cooking area, Phase I. Cf. p. I59, FIG. 6. Scale: 2 m.

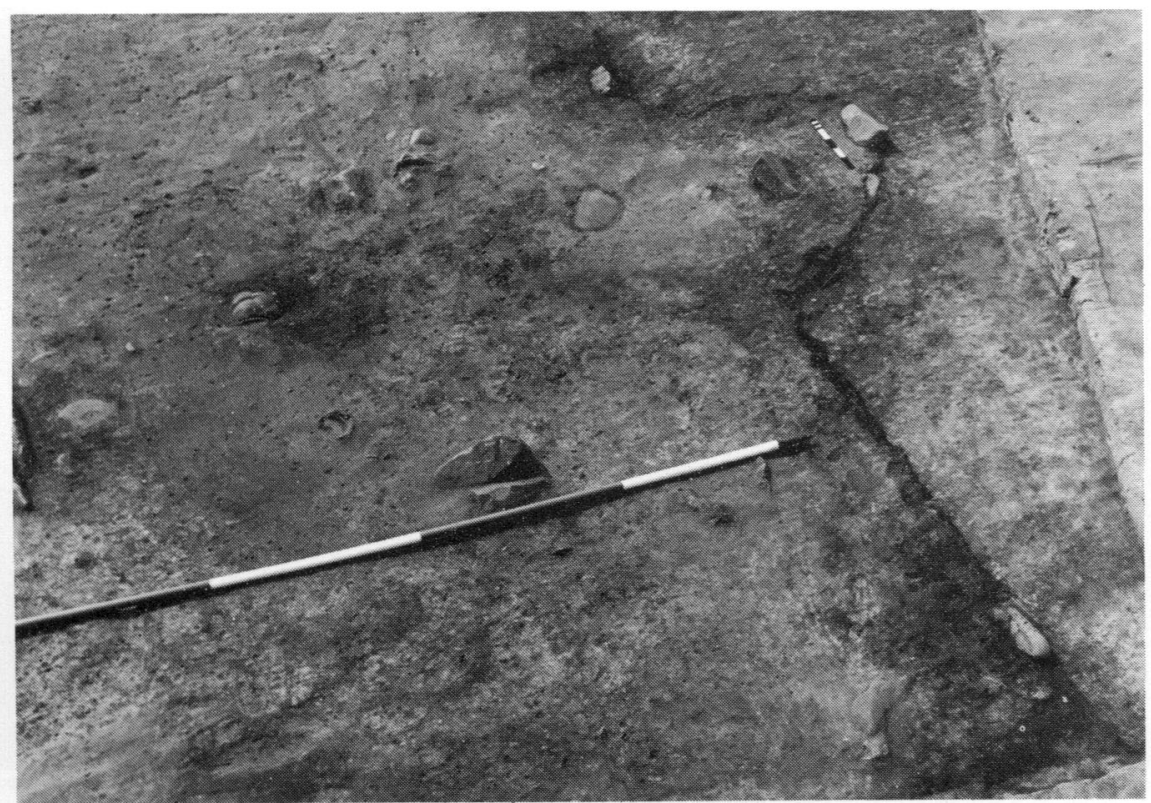

(Photo: T. W. Potter) 


\section{PLATE XII}

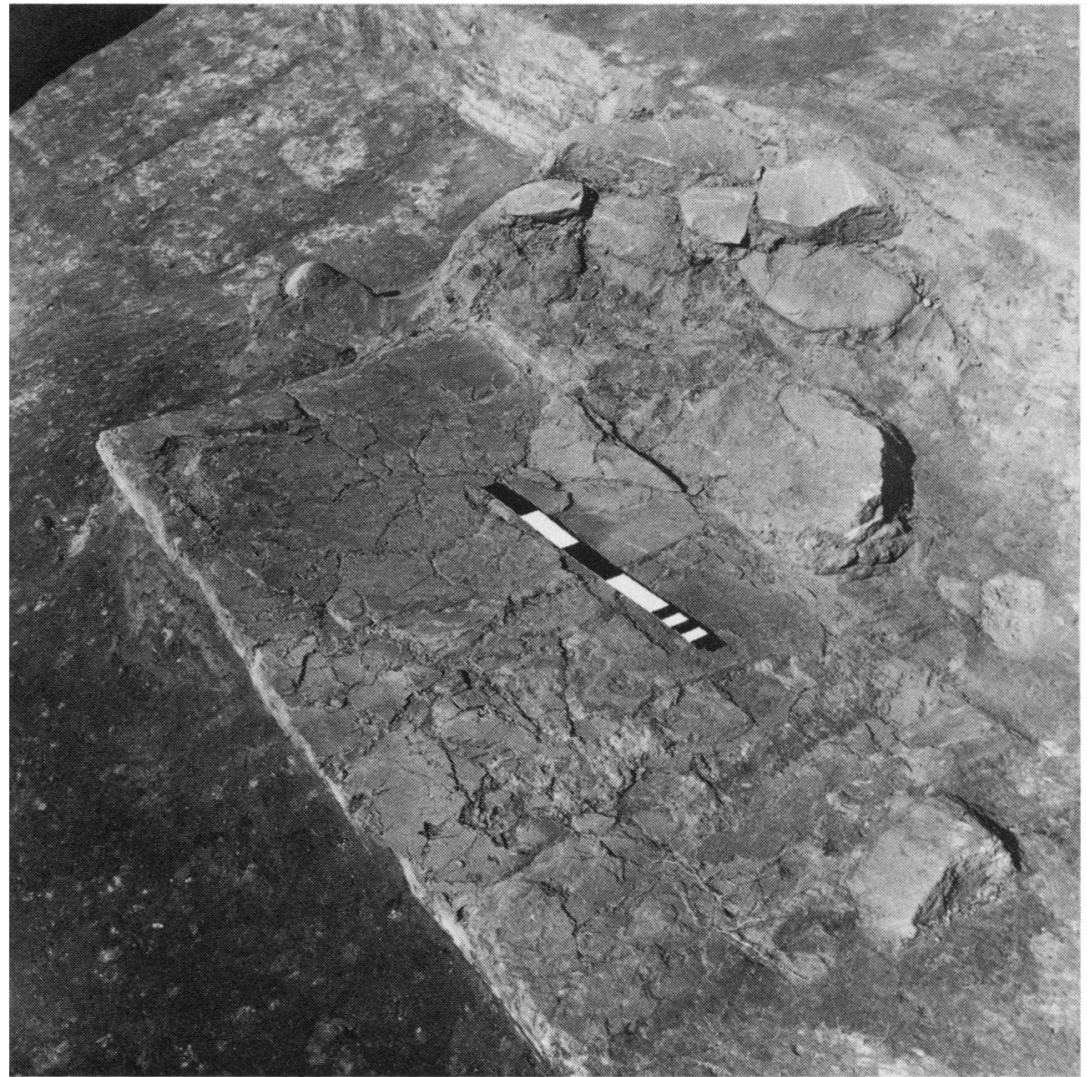

(Photo: T. W. Potter)

A. Biglands. Hearth of Phase II, north-west corner (p. I64).

Note the rampart turves beyond. Scale: $25 \mathrm{~cm}$.

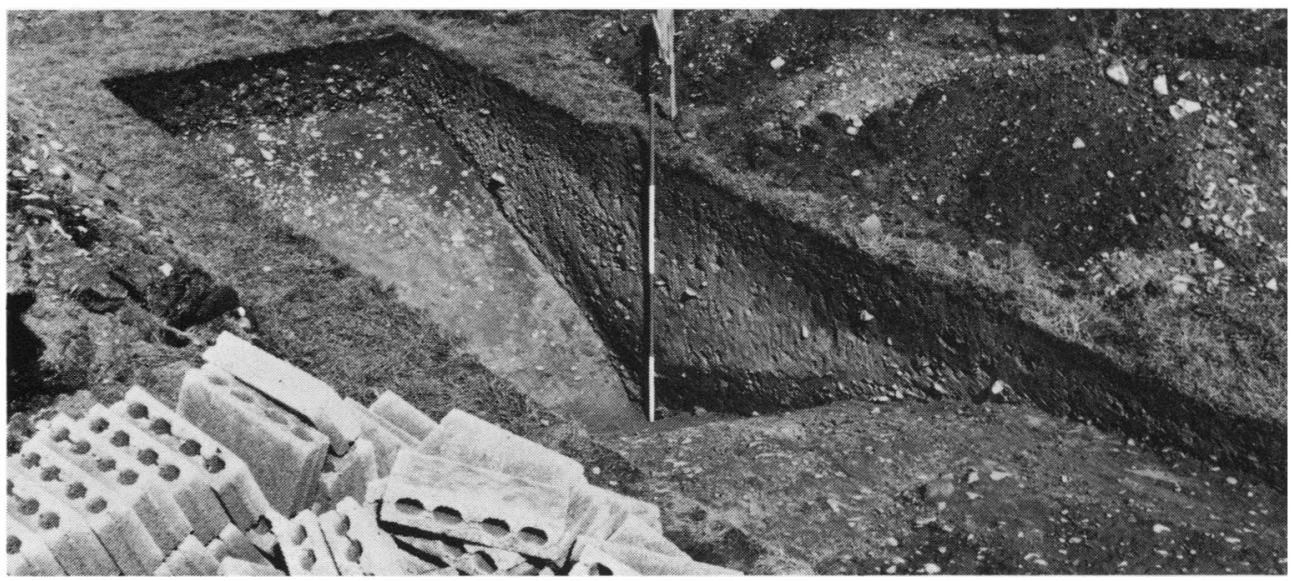

(Photo: T, W. Potter)

B. Biglands. The fortlet ditch. Scale: $2 \mathrm{~m}$. 


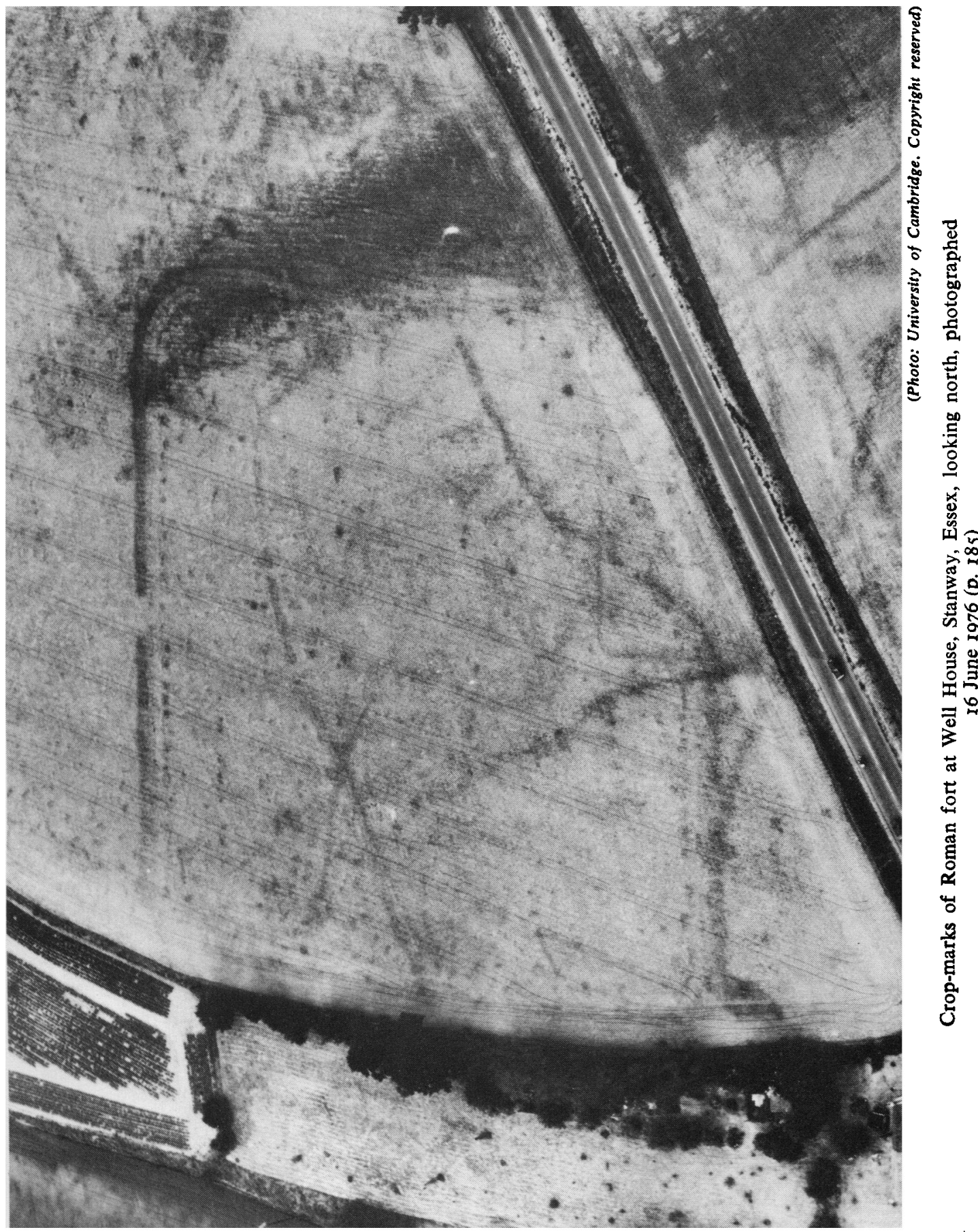




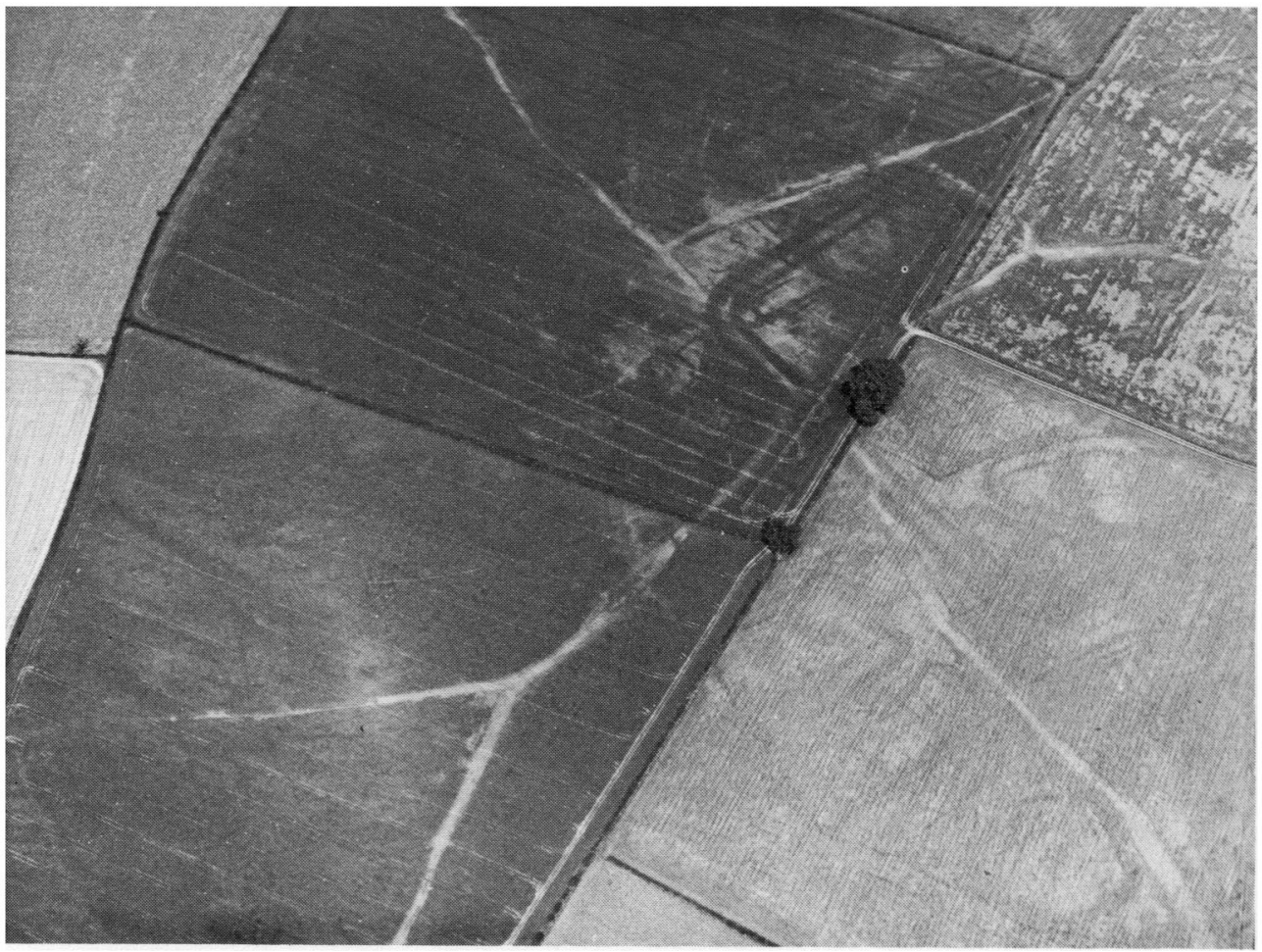

(Photo: D. N. Riley)

A. Kirmington, South Humberside. Crop-marks of settlement and possible fort (p. I89).

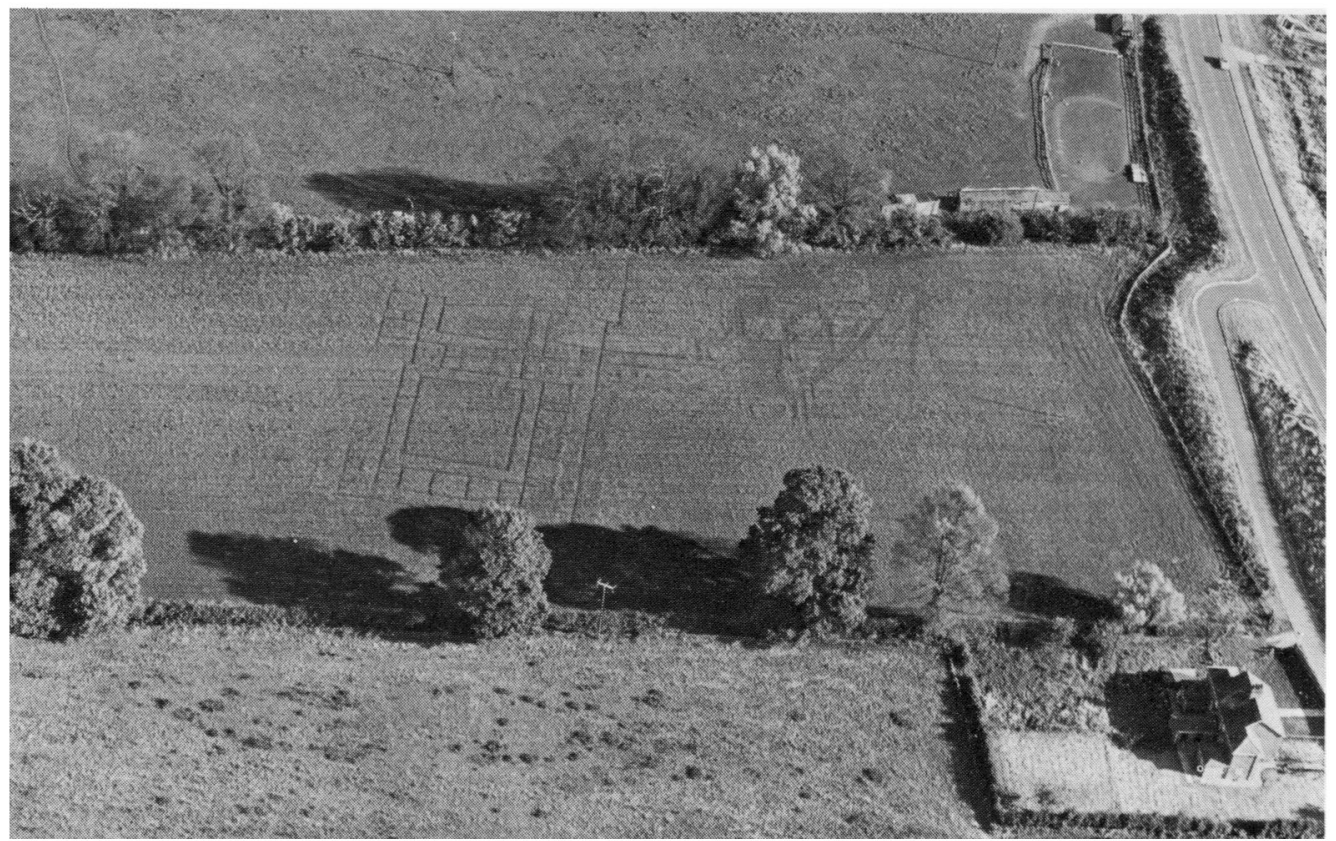

(Photo: B. Hill. Copyright reserved) 


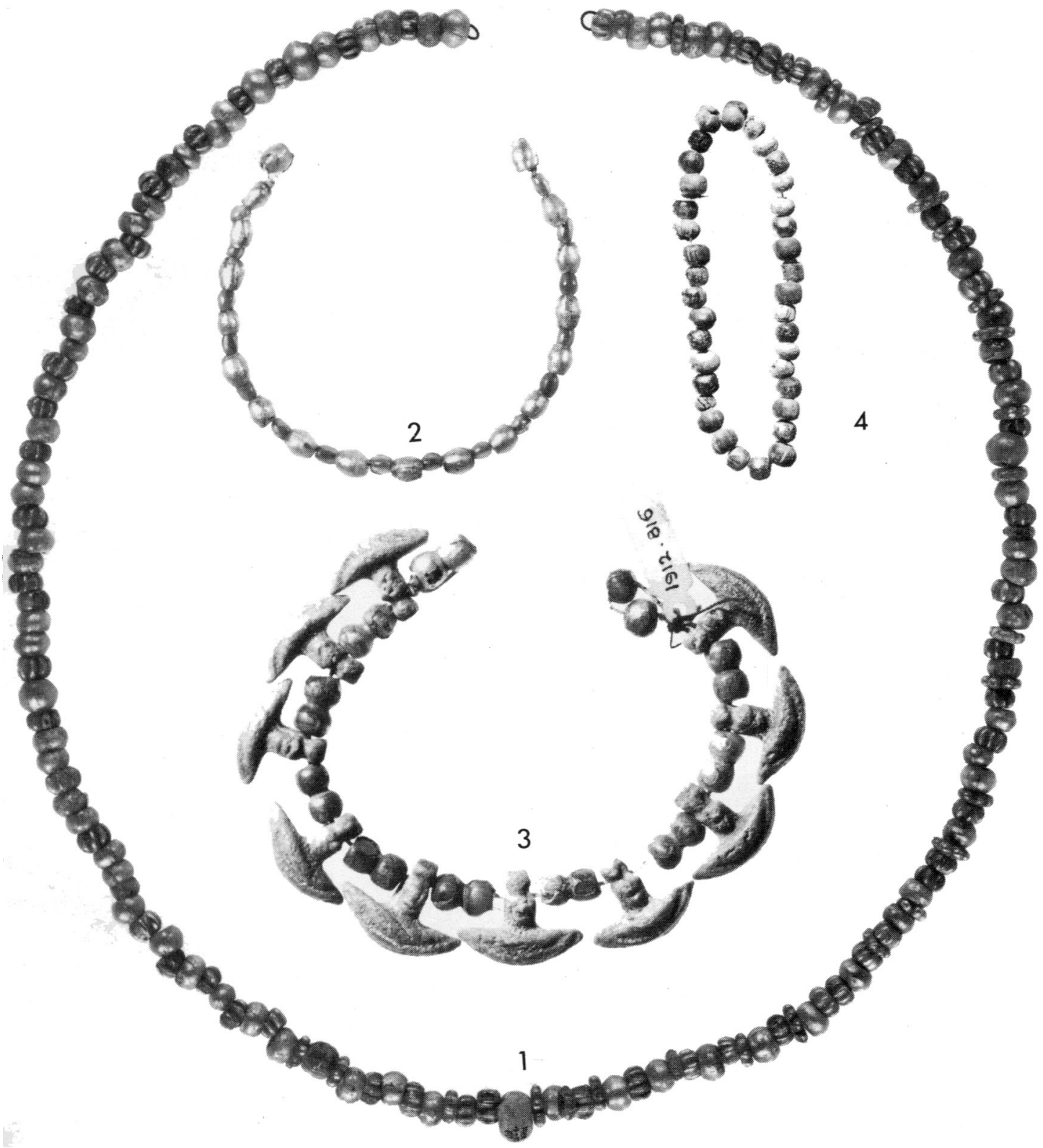

Gold- and (3) Silver-in-Glass Beads (p. 193). (1) Egypt, Ptolemaic, 5/8; (2) Faras, with cornelian beads, first century B.C., I/I; (3I Faras, with turquoise frit drops, first century A.D., I/I; (4) Poieneşti, with other beads, first century B.C., and about $\mathrm{I} / 2$.

(By permission of the British Museum (I), the Ashmolean Museum (2-3) and the Institute of Archaeology, Bucarest (4)). 

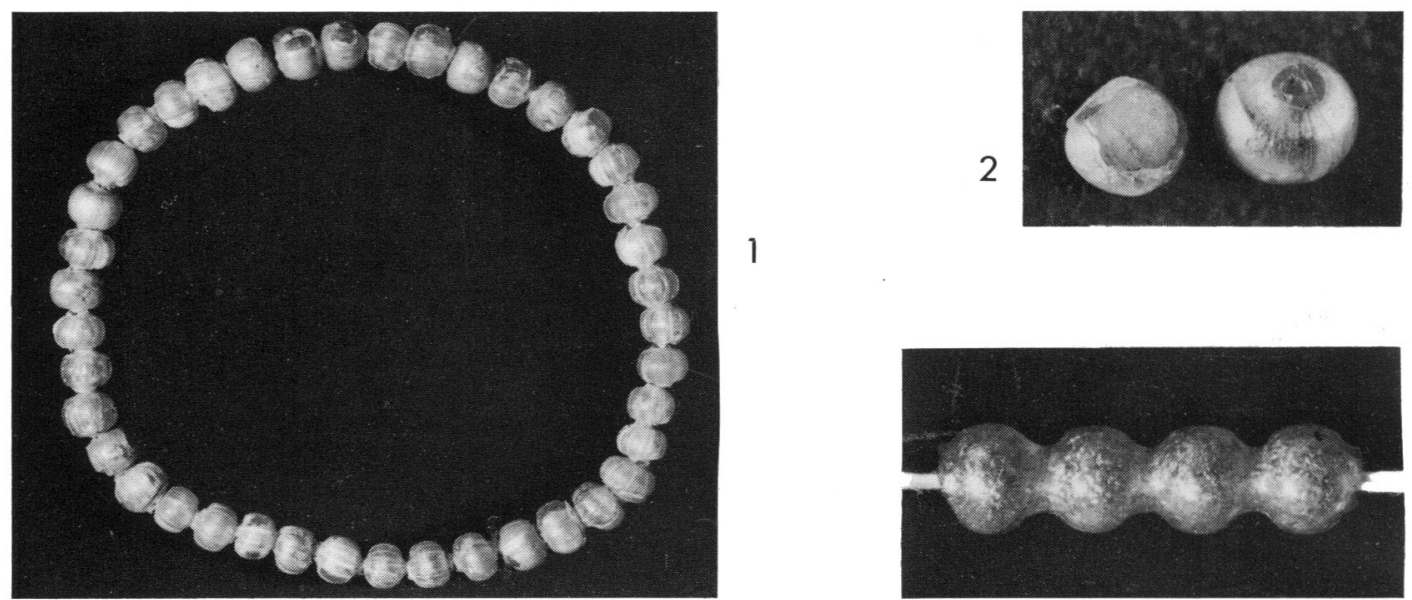

1
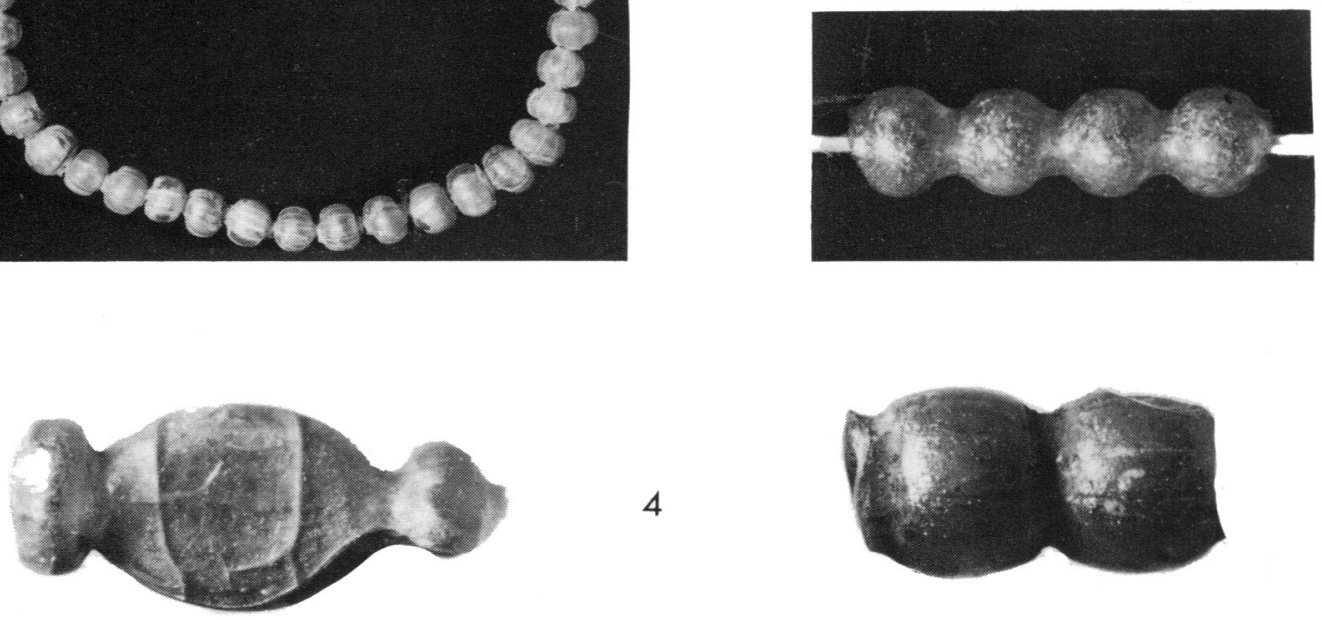

4
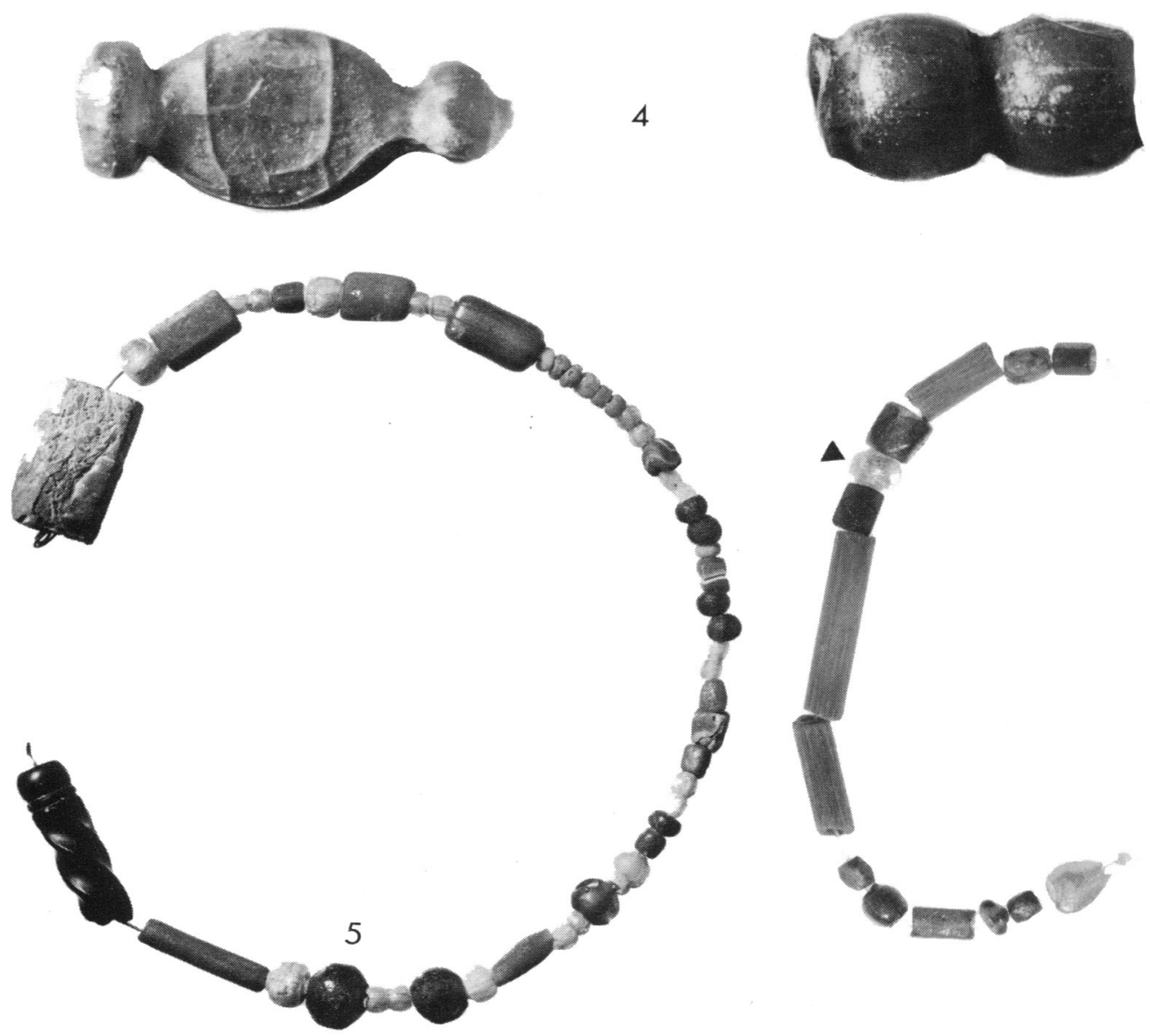

Gold- and (6) Silver-in-Glass Beads (p. 193). (r) Baldock, Antonine cremation-burial, I/I; (2) Caerleon, Antonine-Severan, about $2 / \mathrm{I}$; (3) Dinas Powys, fifth or six century, $4 / \mathrm{I}$; (4) Panticapaeum, second or third century, 4/I; (5) Verulamium, with blue and green glass and a jet bead, fourth-century inhumation-burial, I/I; (6) Winchester-Lankhills, with blue and green glass beads and bronze hooks, fourth-century inhumation-burial, I/I. (By permission of Letchworth Museum, photo Peter Hodge (I), the State Historical Museum, Moscow (4),

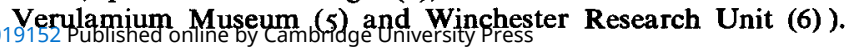




\section{PLATE XVII}
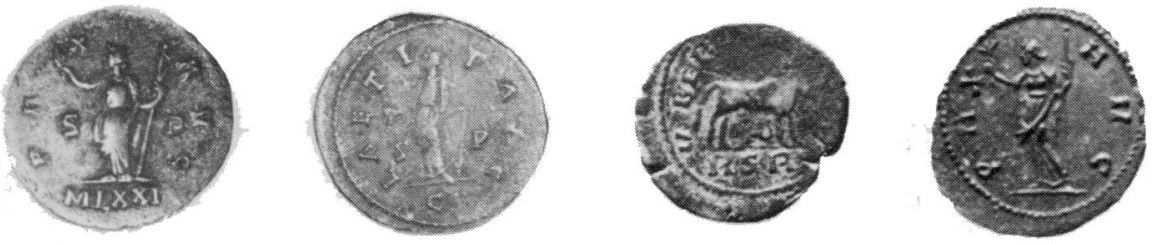

2

3

4
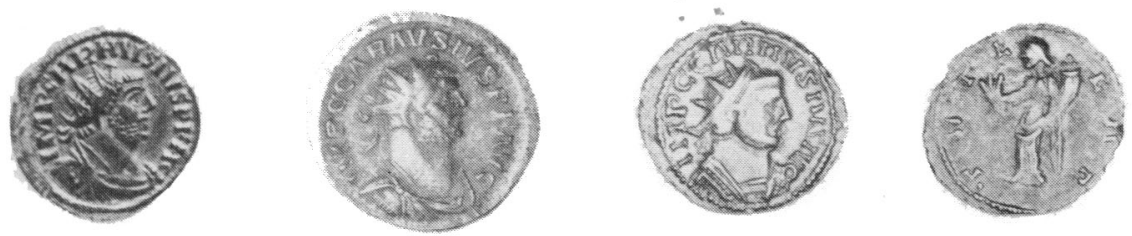

5

6

7

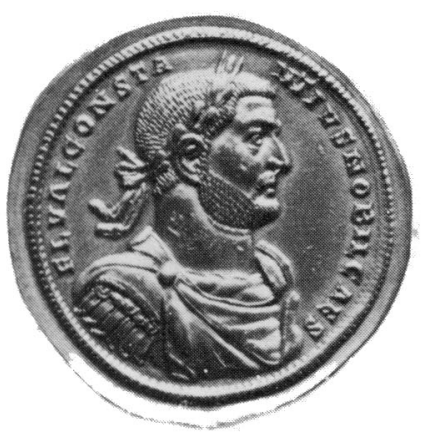

8
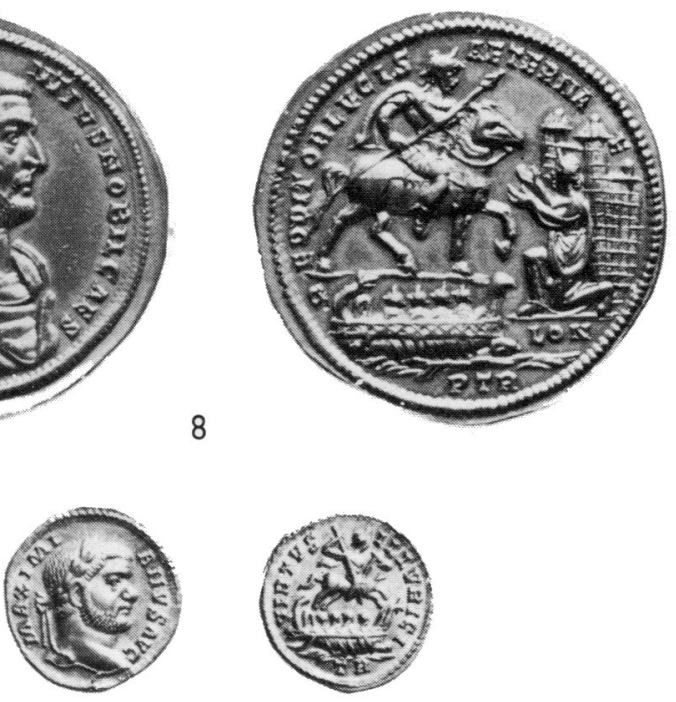

9

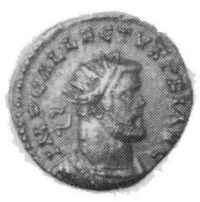

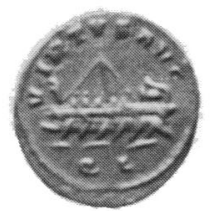

10

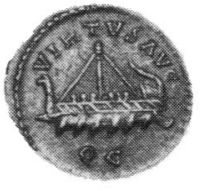

II

Coins and Medallion of Carausius and Allectus (scale I: I) (pp. 284 ff.).

Nos. I, 3-5, 10, by courtesy of the British Museum; No. 9 by that of the Ashmolean Museum. 
PI.ATF. XVIII

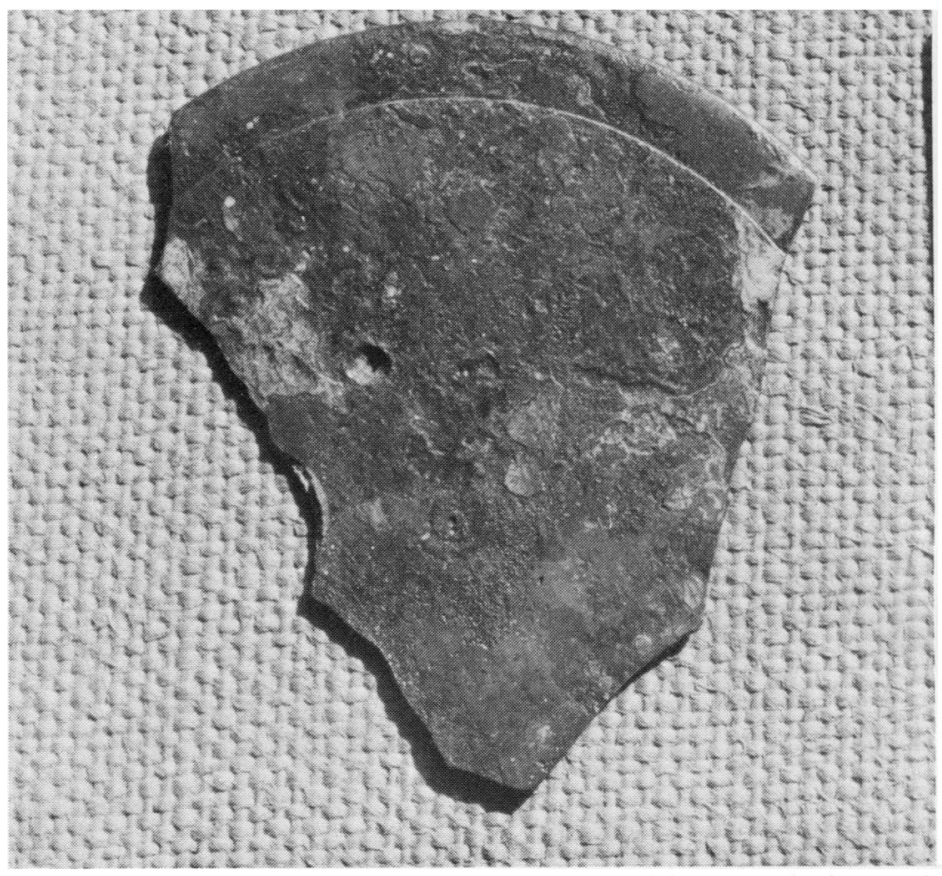

(Photo: G. Lloyd-Morgan)

A. Bronze mirror from Corbridge, Northumberland (p. 335). Scale $\mathrm{I}: \mathrm{I}$.

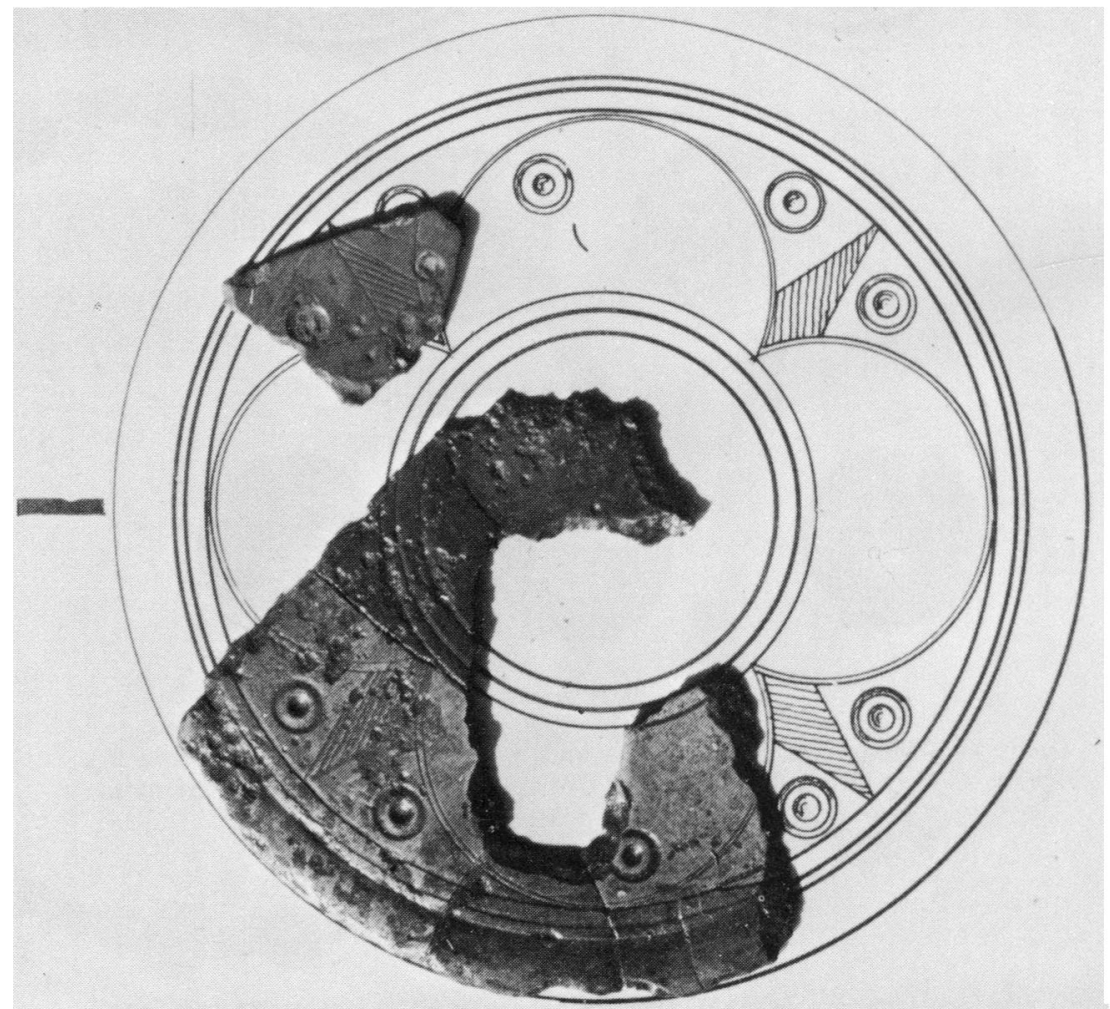

(Photo: G. Lloyd-Morgan) 


\section{PLATE XIX}

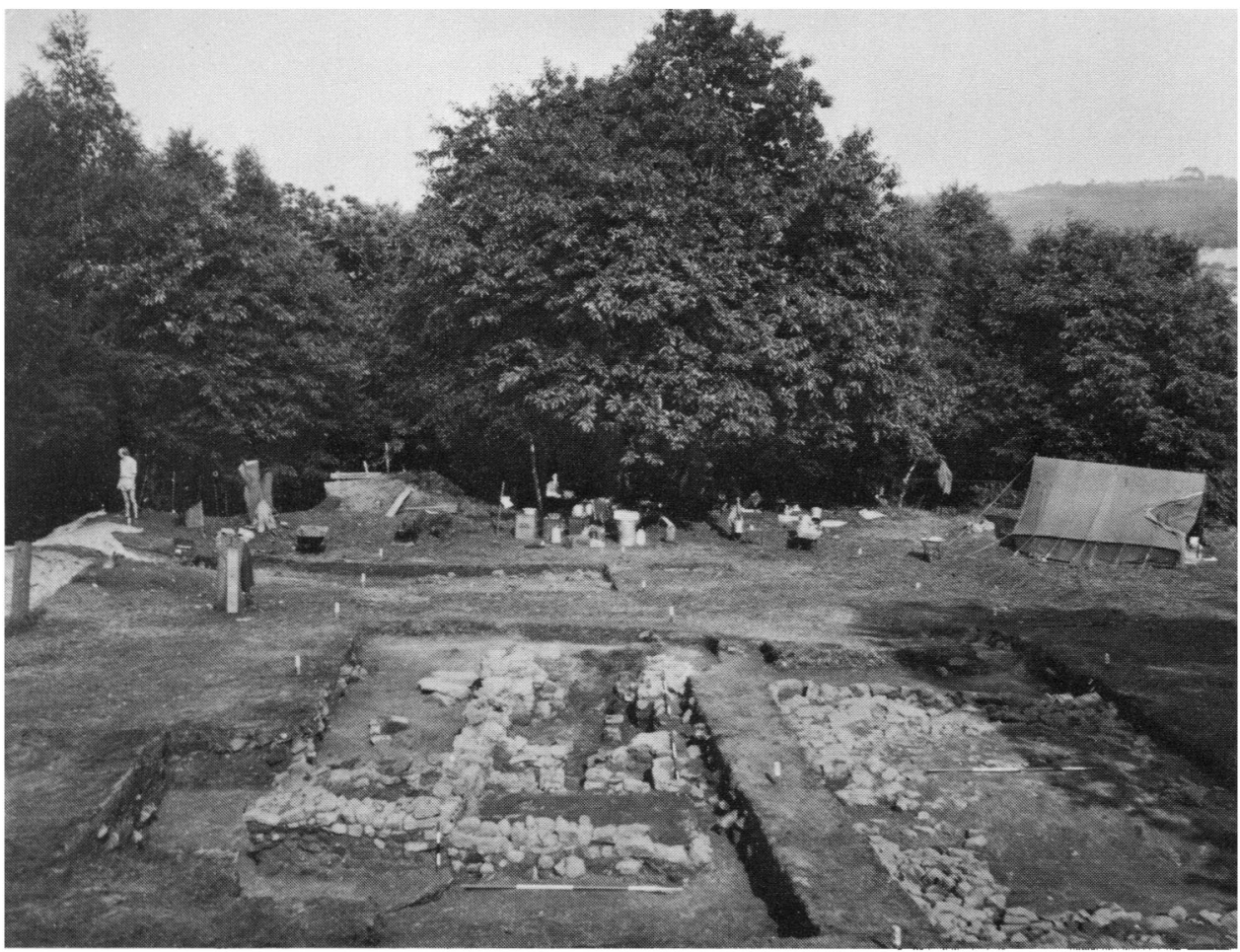

(Photo: J.H. Money)

A. Garden Hill, East Sussex. General view, looking east, of stone platform of Building B (right foreground), Bath building (left foreground), and southern inturn of hill-fort entrance (extreme left middle ground). Scale in half metres (pp. $339 \mathrm{ff}$ ).

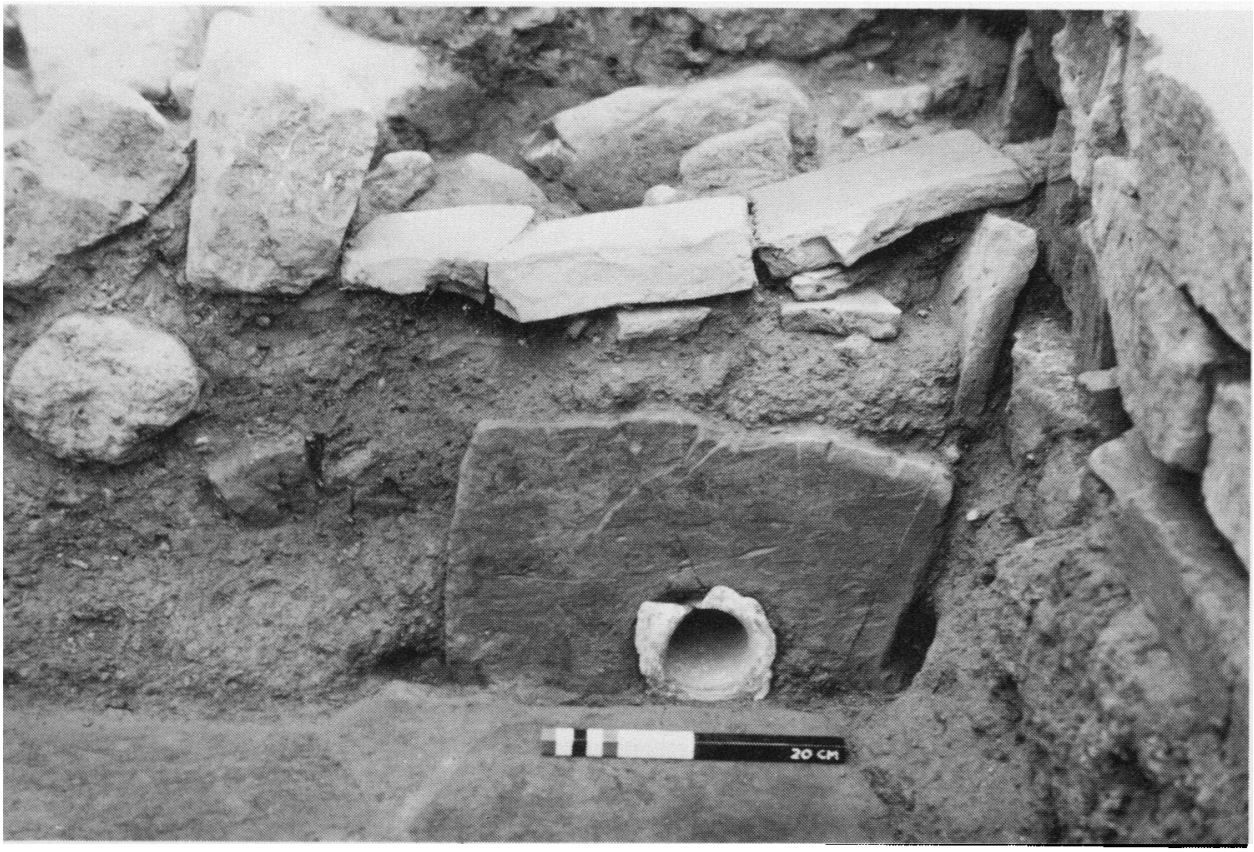

(Photo: J. H. Money)

B. Garden Hill. N.W. corner of cold room, showing rough masonry and remains of opus signinum which plastered the walls, quarter-moulding at junction of wall and floor, lead out-

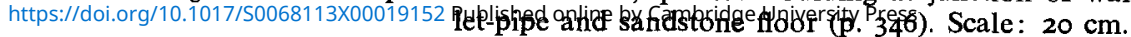




\section{PLATE XX}

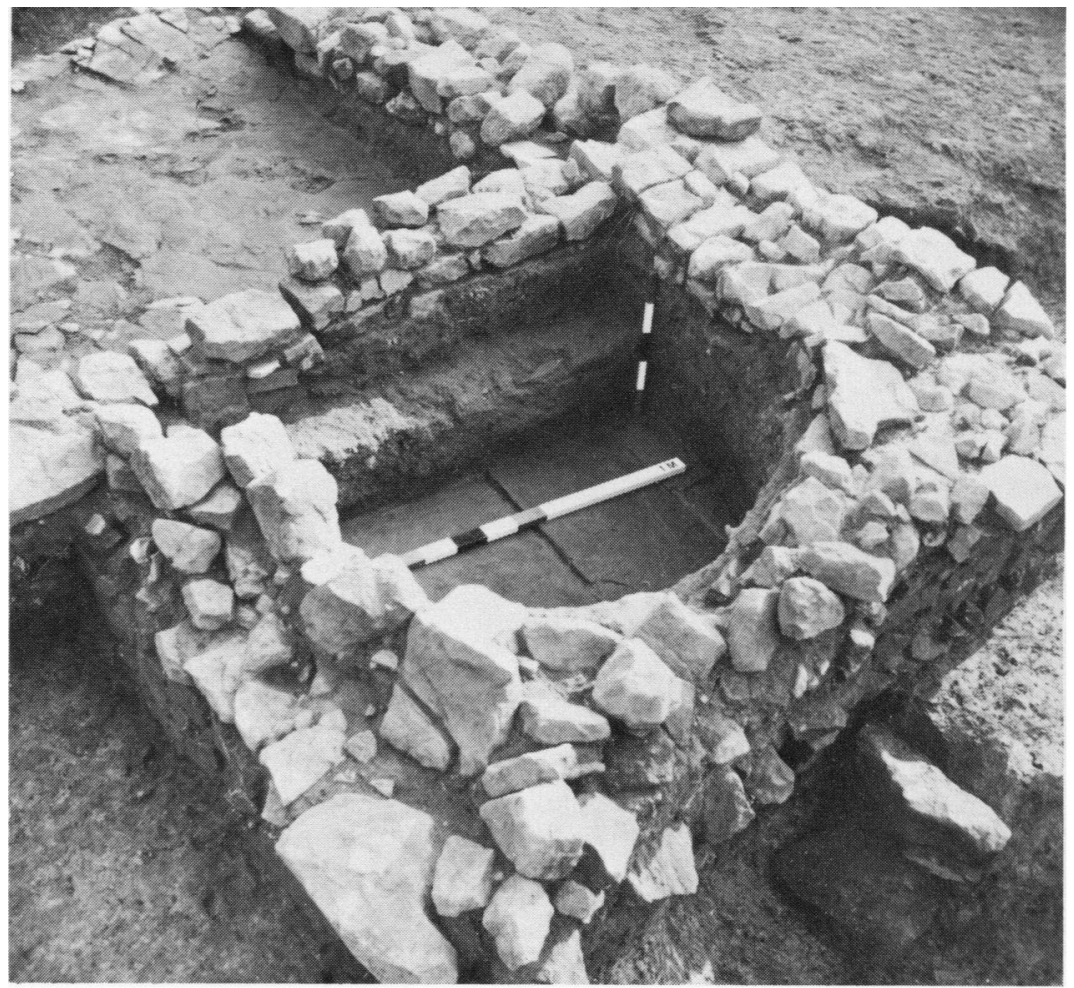

(Photo: J. H. Money)

A. Garden Hill, East Sussex. Cold plunge and cold room of bath building, showing rough stonework plastered with opus signinum and stone floor (p. 346). Scale: I m.

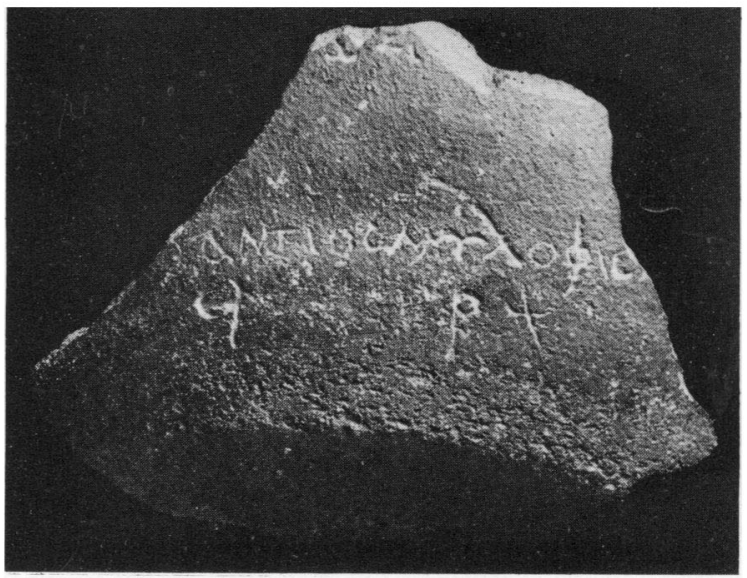

(Photo: R. L. Wilkins)

B. Inscribed sherd from River Thames at Amerden, Buckinghamshire (p. 279). Scale: 2:3.

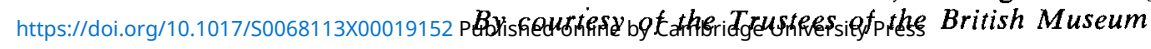


PLATE XXI
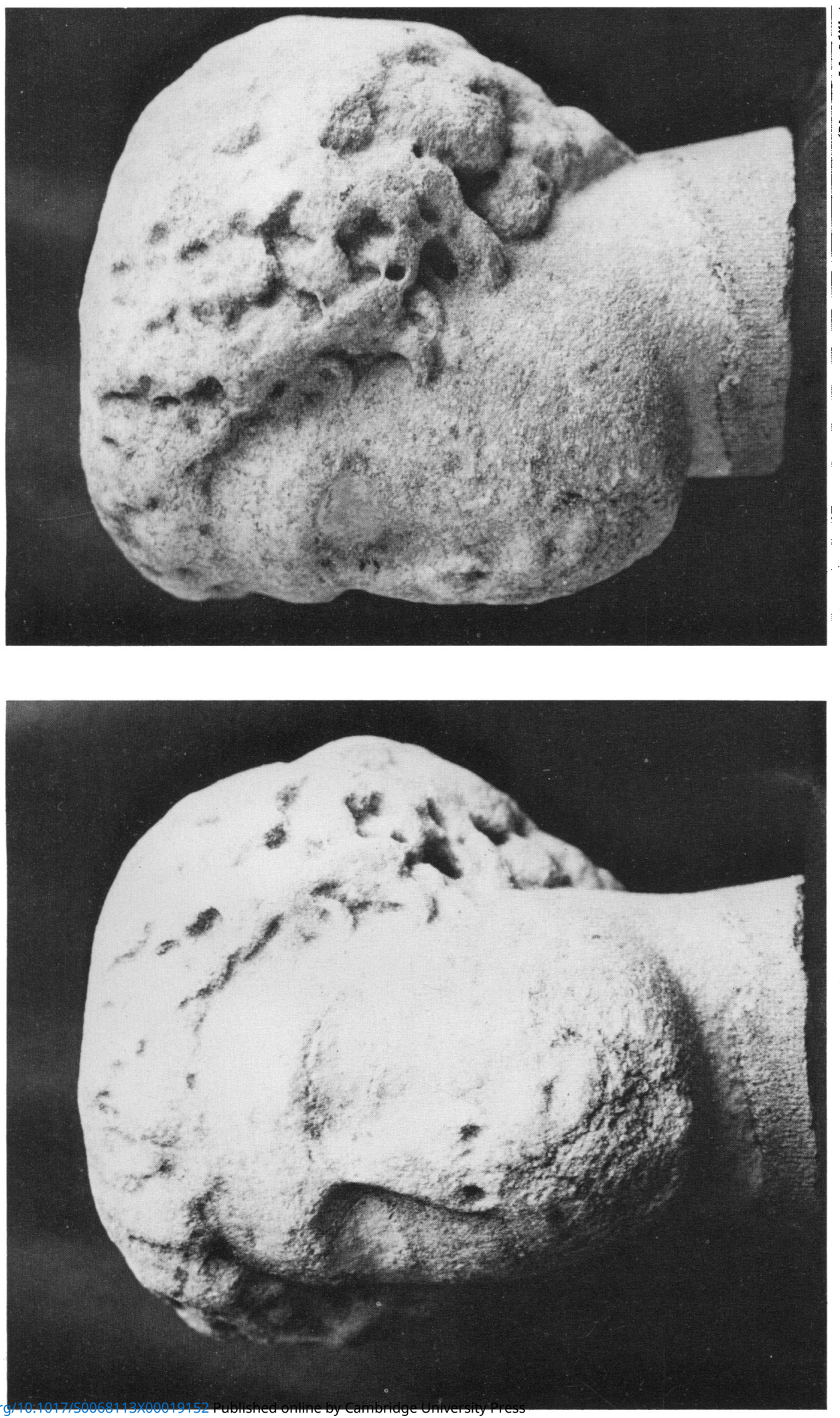


\section{PLATE XXII}

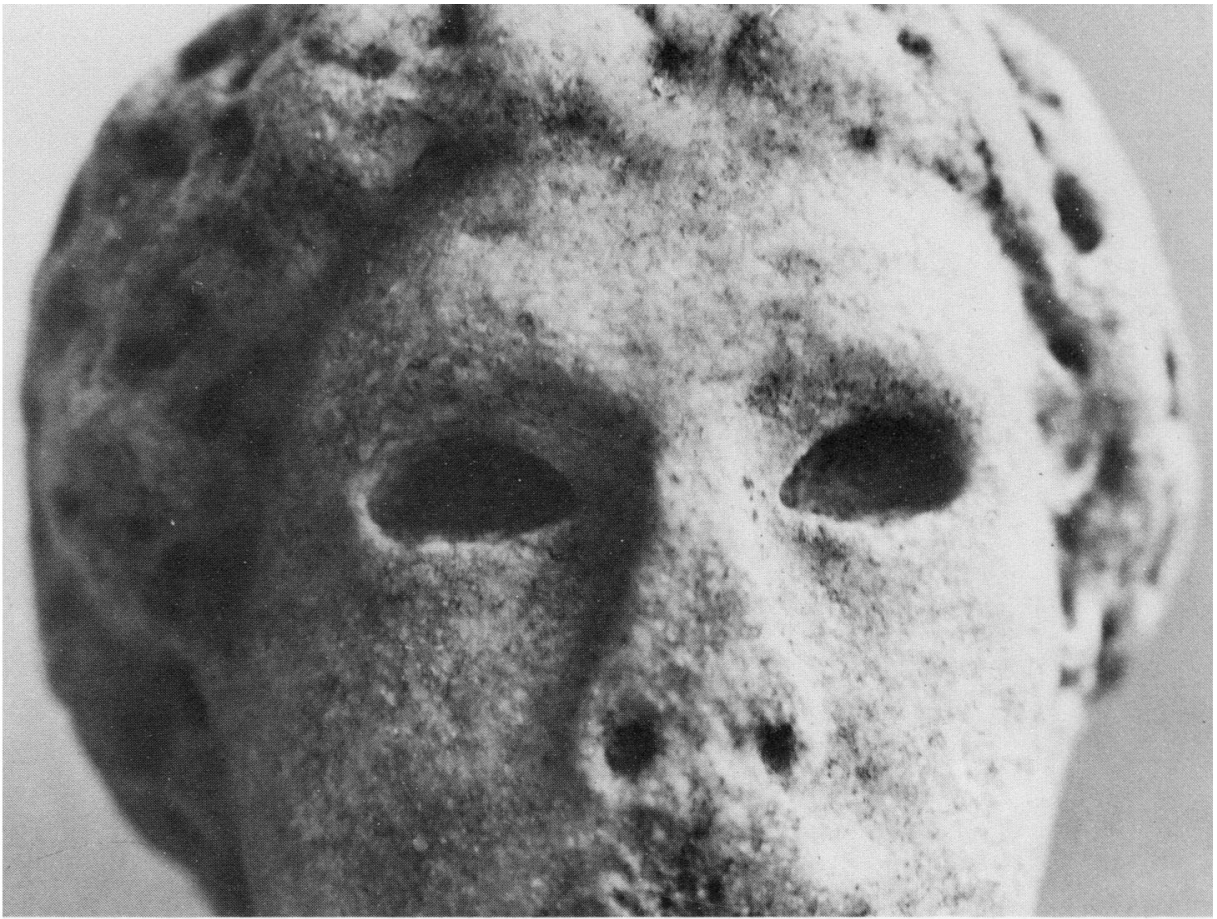

(Photos: M. Millet)

A. Marble head from Crondall Parish Church (p. 35r).

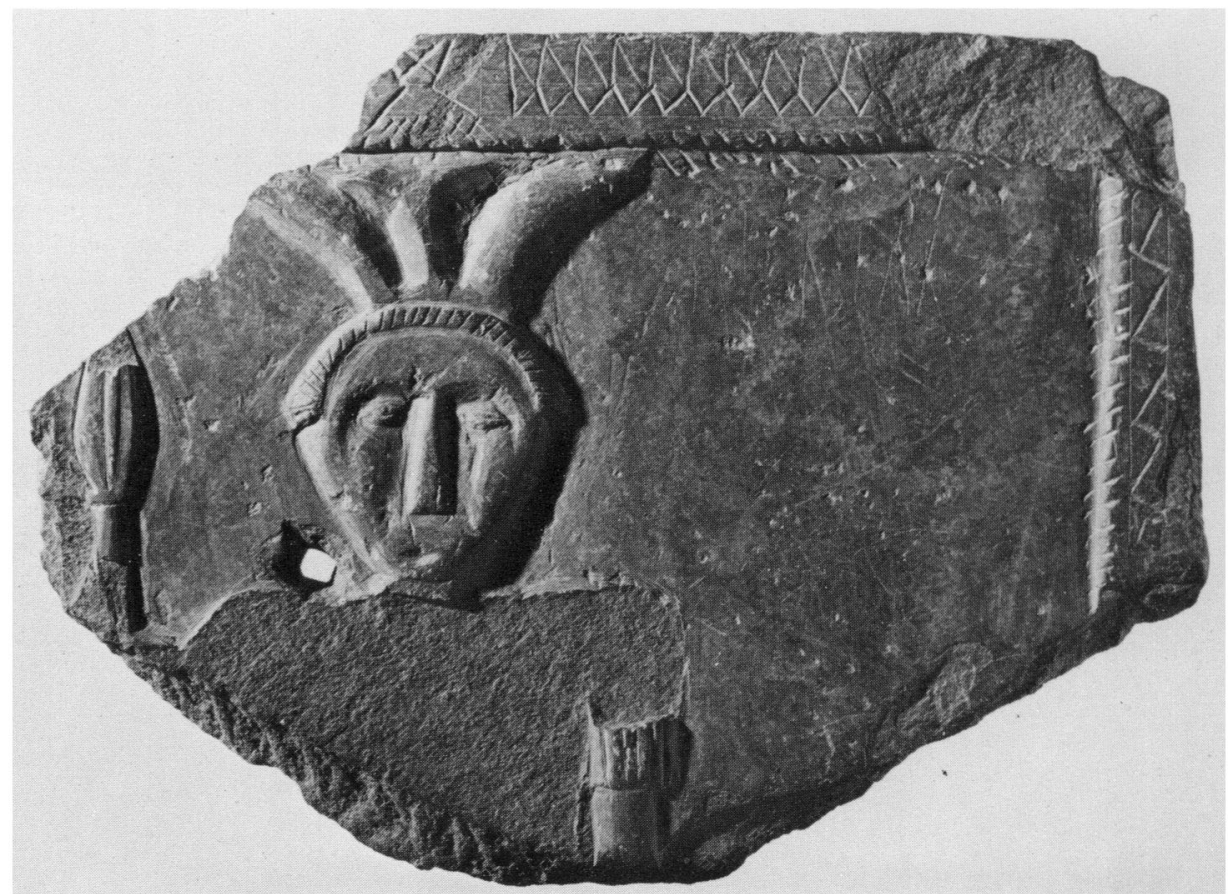

(Photo: T. Middlemass)

B. Caernarvon: relief panel showing Mars (p. 358). Scale: I : 2. 
PLATE XXIII

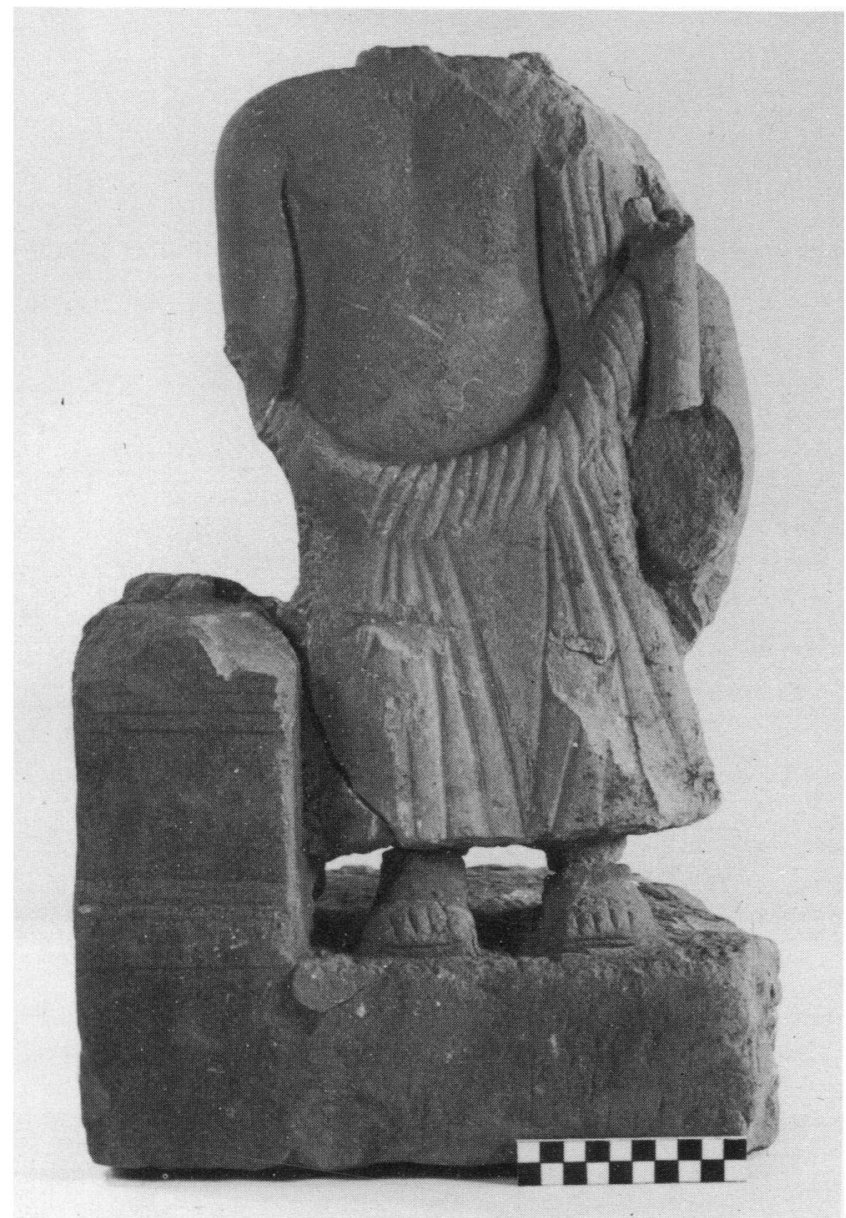

(Photo: Carliste Museum)

A. Burgh by Sands, Cumbria: statue of a Genius (p. 376). Height: $495 \mathrm{~mm}$.

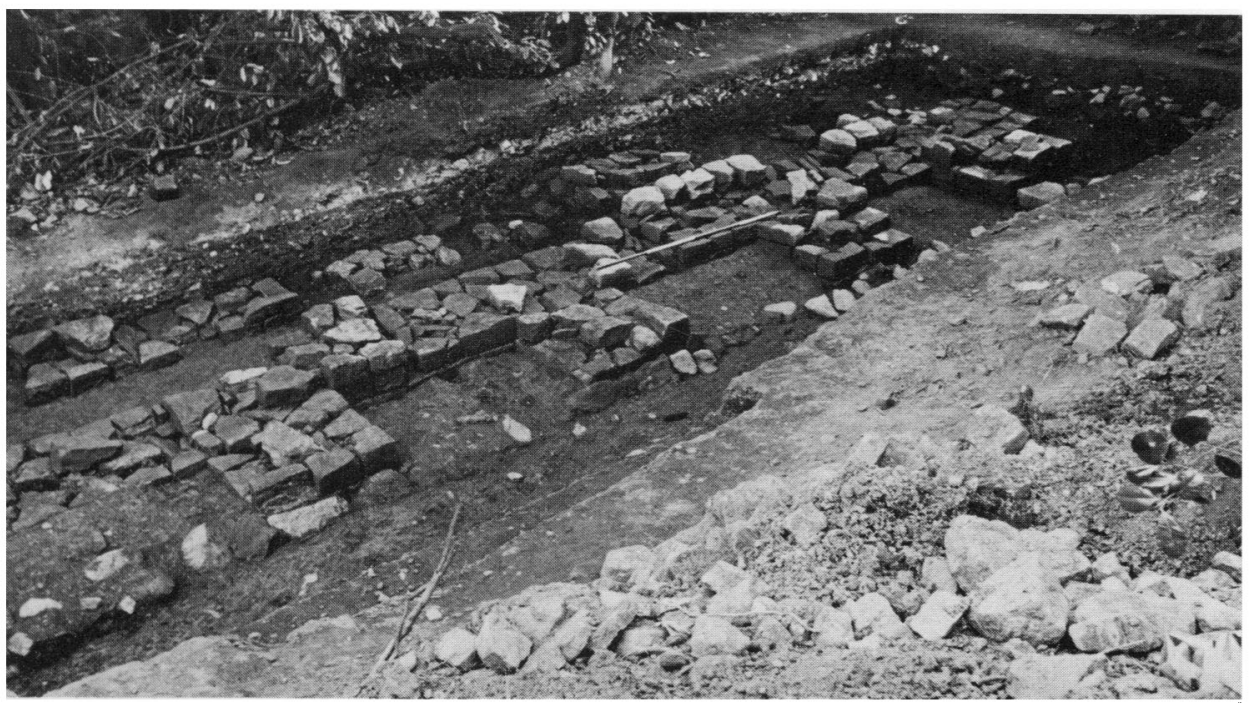

(Photo: Dr V. A. Maxfield; Crown copyright) 
PLATE XXIV

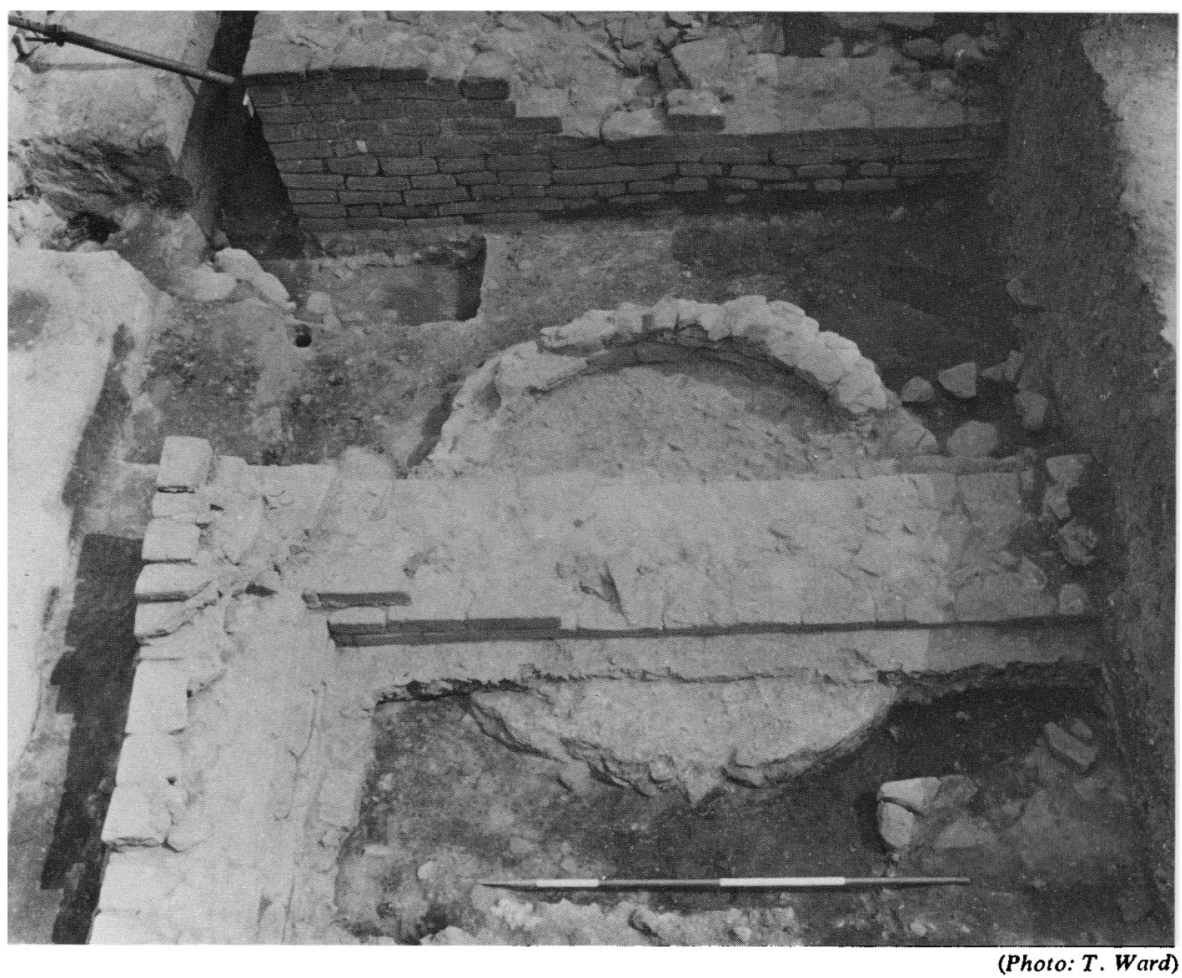

A. Chester, Abbey Green: rampart-building of c. A.D. 100 on the site of a Flavian bread-oven, Newstead's rampart-building (2) is in background (pp. 386-7).

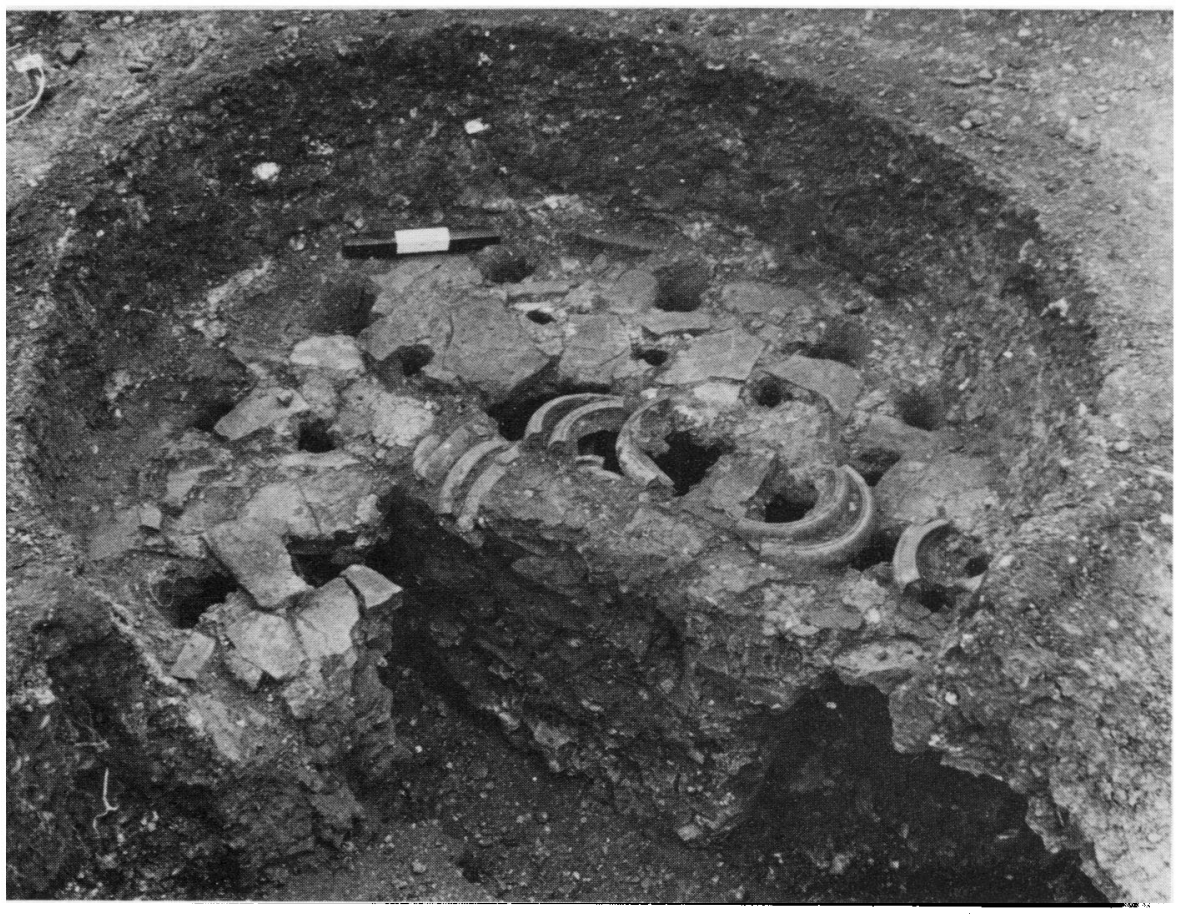

(Photo: A. Gregory)

B. Ellingham, Norfolk: oven floor of pottery-kiln, after removal of clay skin, looking

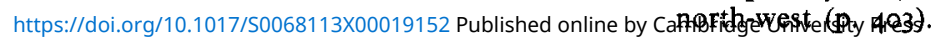




\section{PLATE XXV}

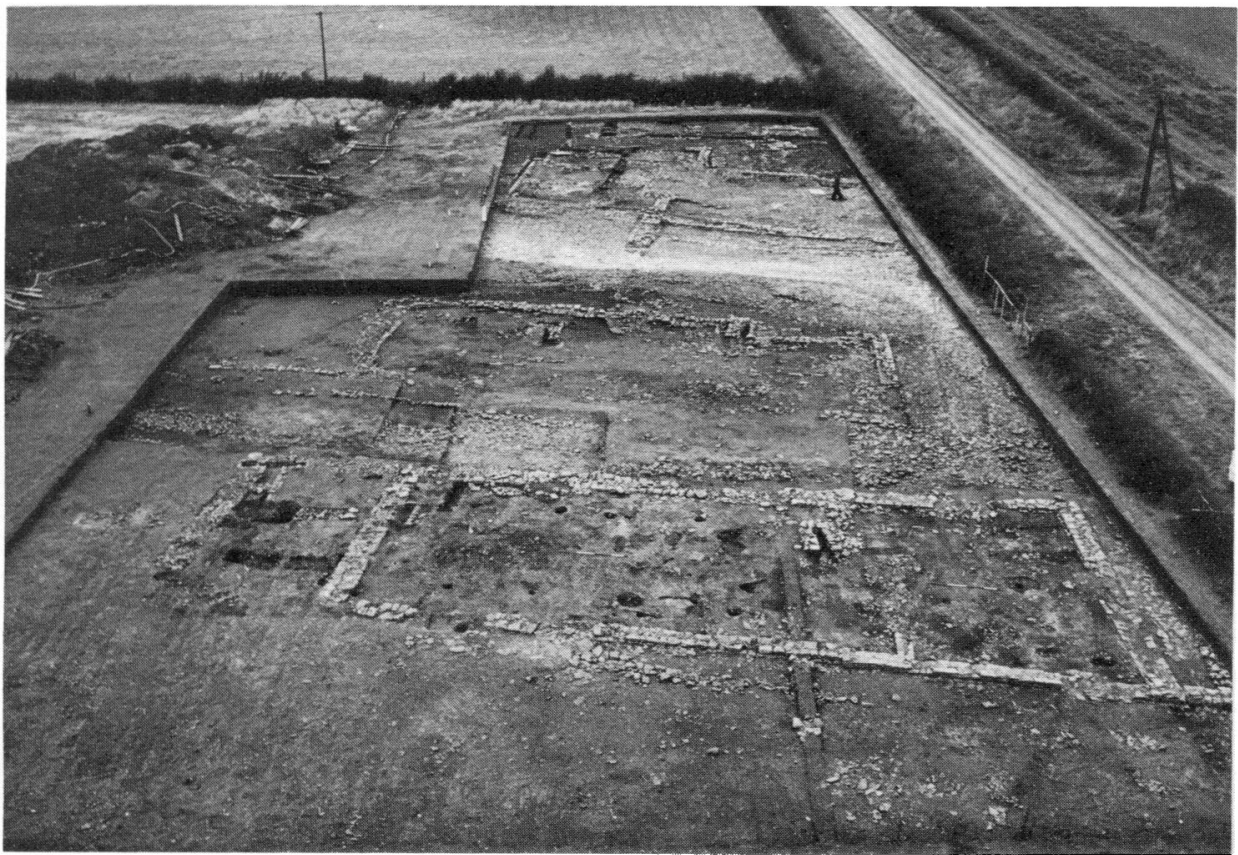

(Photo: R. F. Smith)

A. Hibaldstow, S. Humberside: general view of the site looking north (p. 389).

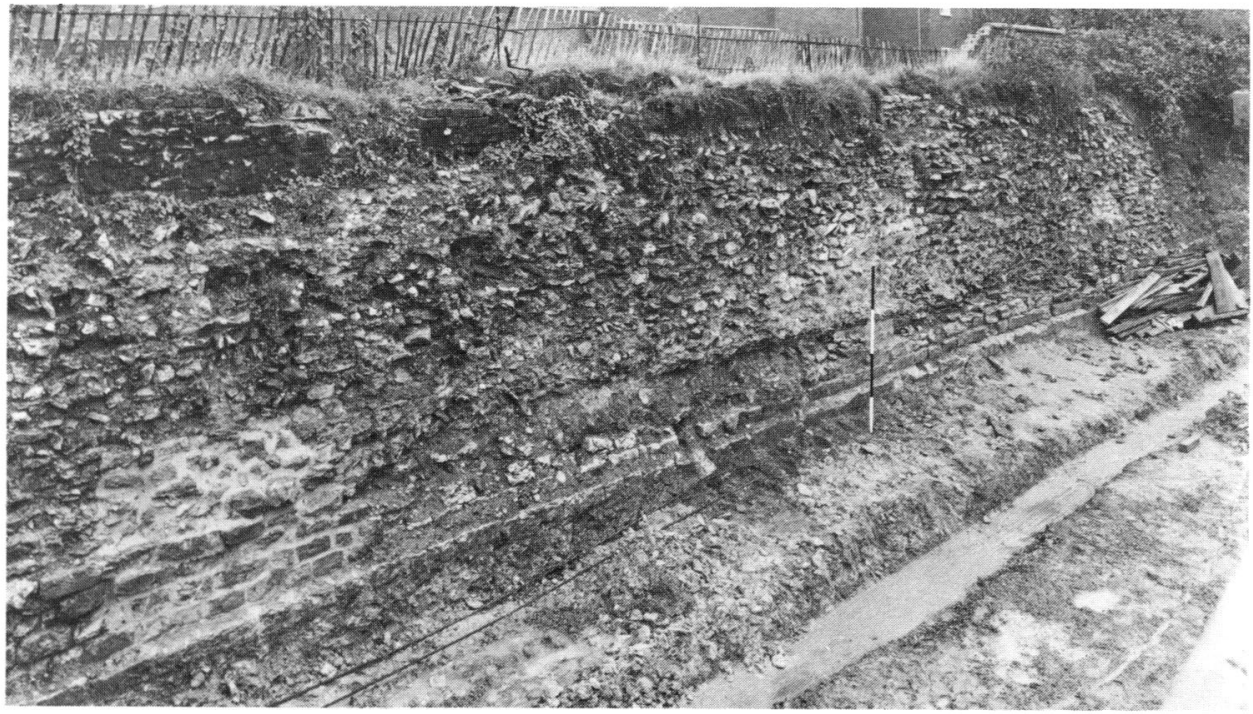

(Photo: H. N. Hawley)

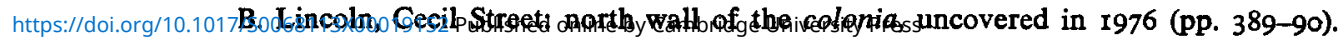




\section{PLATE XXVI}

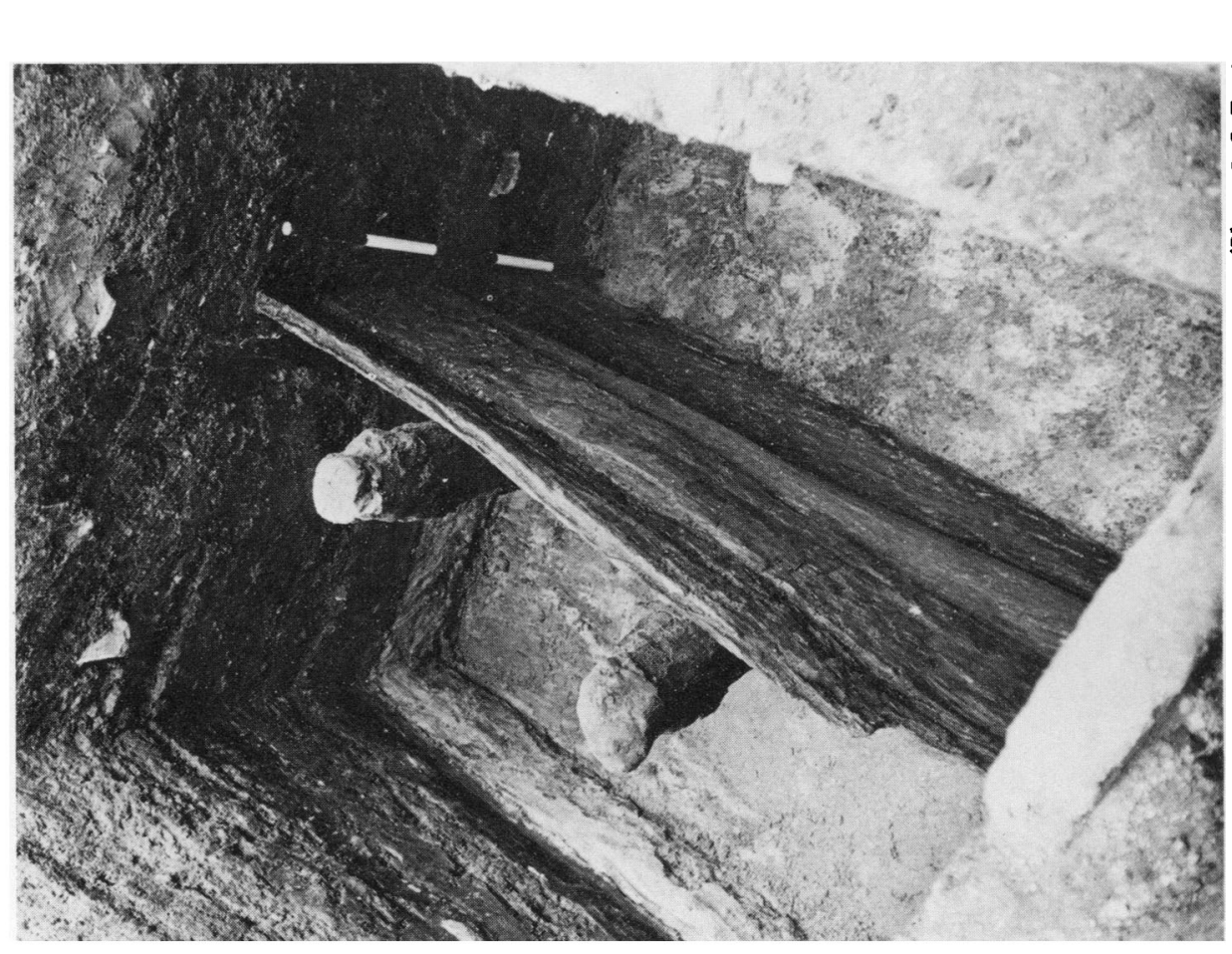

o 节

占尔

¿

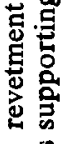

实总

矛

范

它宁

$+8$

运

क 3

도ㅇㅝㅗ

工

는

용

눙

ㅇํㅇㅇ

송

in

용

萧

密

คำ

我密

$\dot{\infty}$

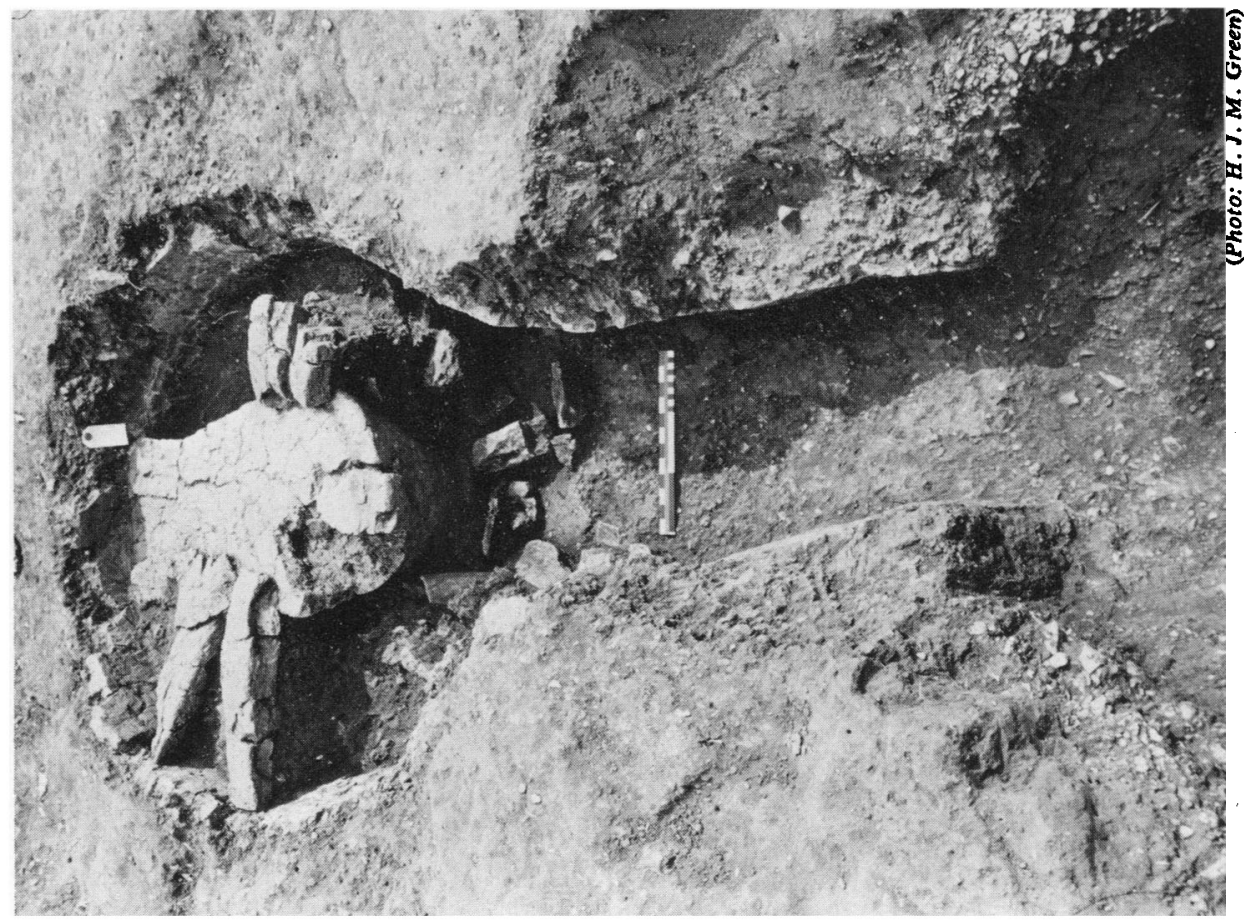

B

물

今

光

总

章

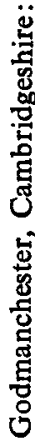




\section{PLATE XXVII}
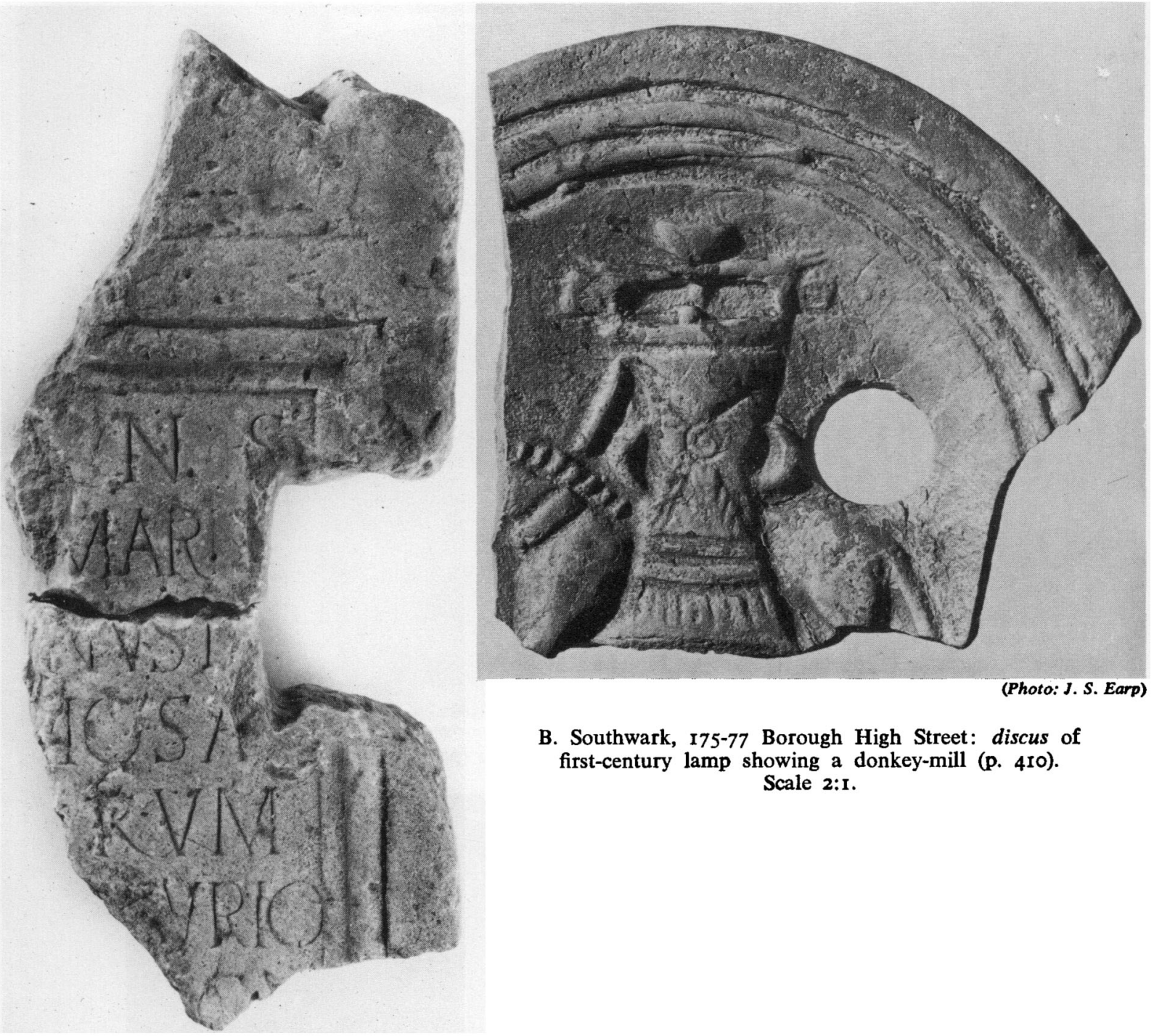

(Photo: H. N. Hawley for Lincoln Archaeological Trust; copyright reserved)

A. Lincoln, St. Martin's Church: inscribed tombstone (p. 428, No. 9). Scale $1: 6$.

B. Southwark, 175-77 Borough High Street: discus of first-century lamp showing a donkey-mill (p. 410). Scale 2: $r$.

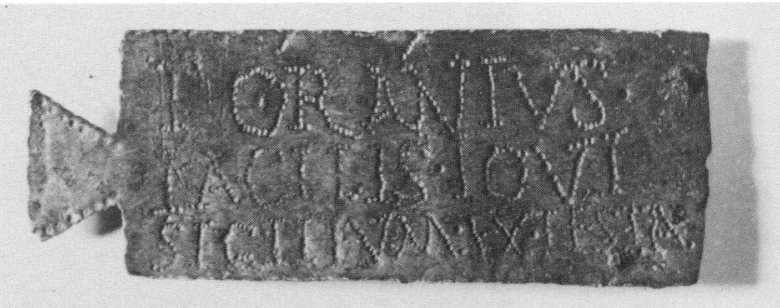

(Photo: C. W. Holby; copyright Colchester and Essex Museum)

C. Colchester, Temple 2: inscribed bronze plaque (p. 427, No. 7). Scale I: I 


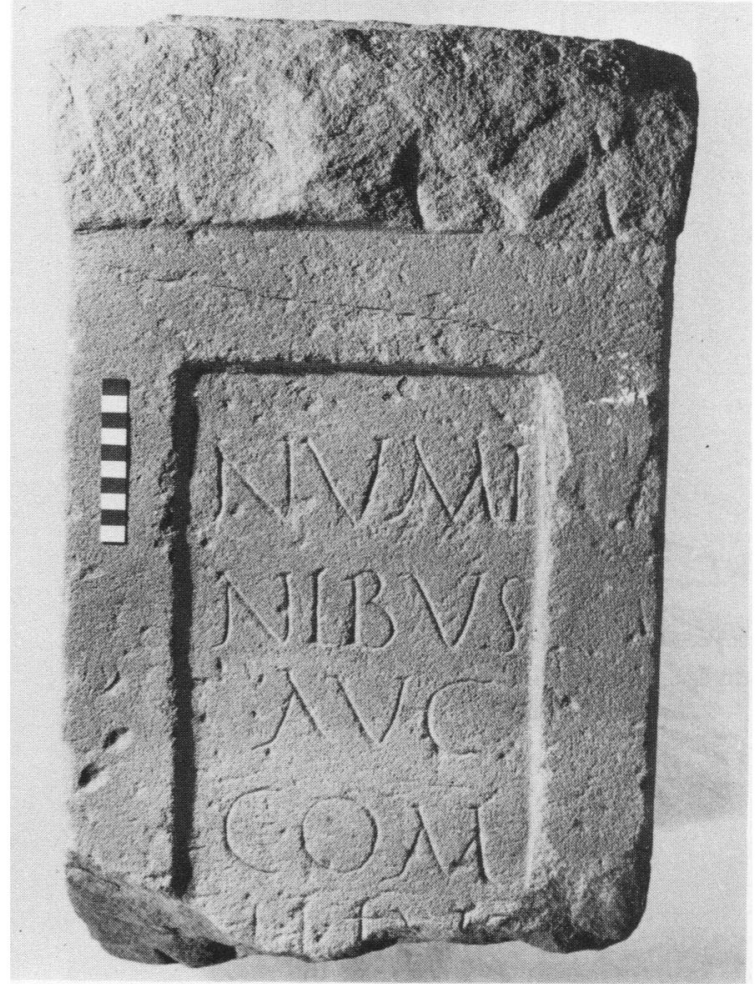

(Photo: T. E. Ward; copyright Grosvenor Museum)

A. Chester, Castle Street: inscribed altar (p. 429, No. 16). Scale: 1:6.

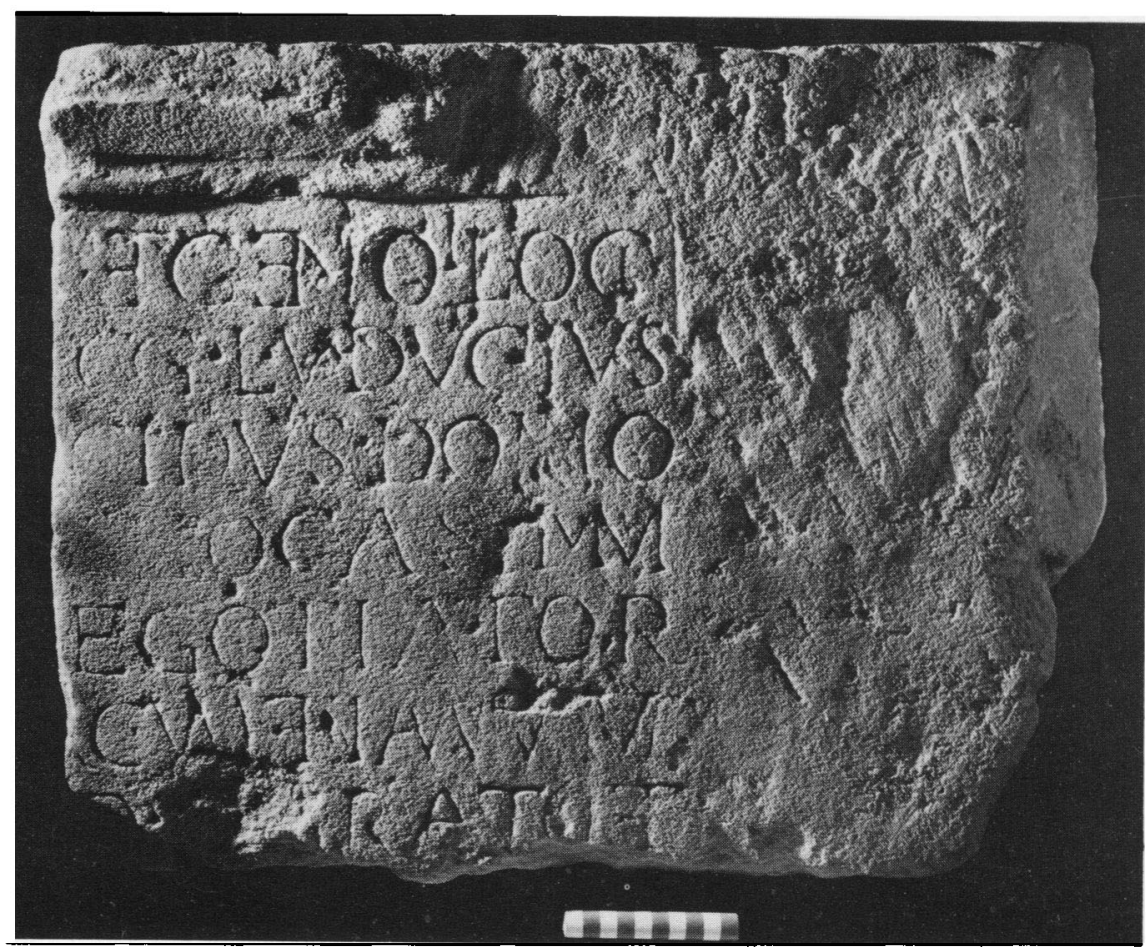

(Photo: M. S. Duffy; copyright, York Archaeological Trust)

B. York Clementhorpe dedication-slab of LunViducius Placidus (p. 430, No. I8). Scale: I : 5. 
PLATE XXIX

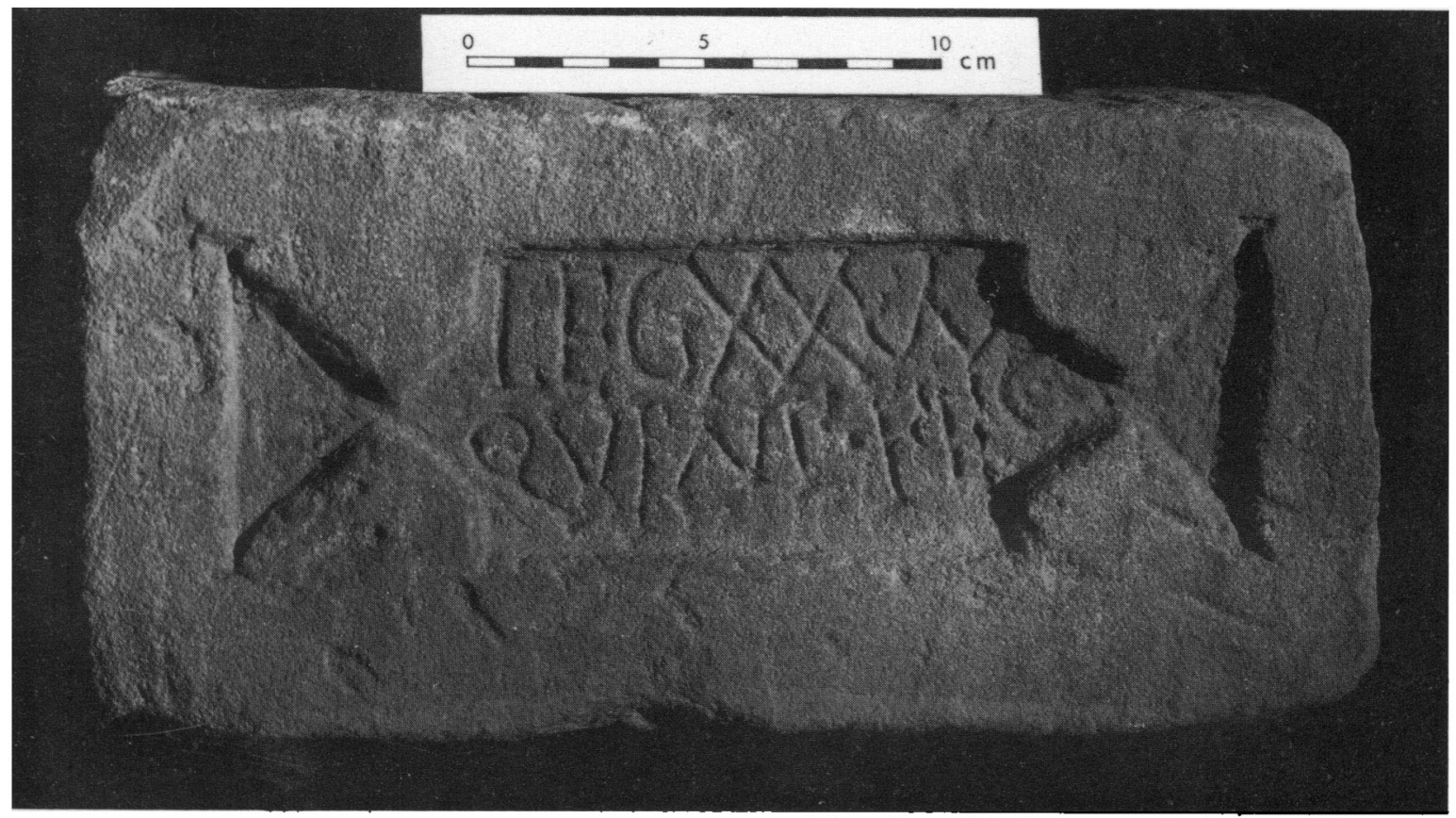

(Photo: Dept. of the Environment, Scotland; copyright reserved) A. New Kilpatrick, Bearsden: inscribed building-stone (p. 433, No. 32). Scale I: 2.

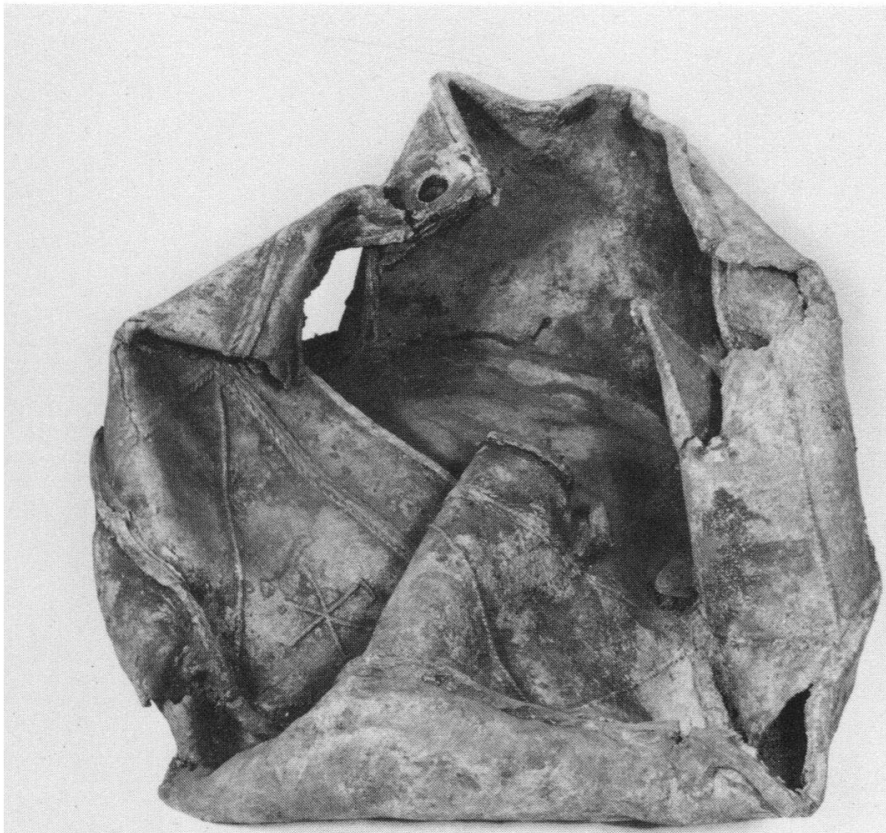

(Photo: H. N. Hawley; copyright reserved)

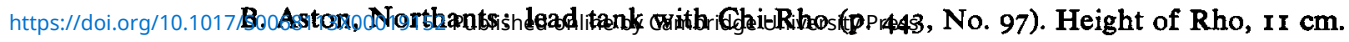

